Portland State University

PDXScholar

Summer 1-17-2014

\title{
Effects of Ethnicity and Gender on Sixth-Grade Students' Environmental Knowledge and Attitudes After Participation in a Year-Long Environmental Education Program
}

Rachel Stagner

Portland State University

Follow this and additional works at: https://pdxscholar.library.pdx.edu/open_access_etds

Part of the Science and Mathematics Education Commons Let us know how access to this document benefits you.

\section{Recommended Citation}

Stagner, Rachel, "Effects of Ethnicity and Gender on Sixth-Grade Students' Environmental Knowledge and Attitudes After Participation in a Year-Long Environmental Education Program" (2014). Dissertations and Theses. Paper 1539.

https://doi.org/10.15760/etd.1538

This Thesis is brought to you for free and open access. It has been accepted for inclusion in Dissertations and Theses by an authorized administrator of PDXScholar. Please contact us if we can make this document more accessible: pdxscholar@pdx.edu. 
Effects of Ethnicity and Gender on Sixth-Grade Students' Environmental Knowledge and Attitudes After Participation in a Year-Long Environmental Education Program

by

Rachel Miriam Stagner

A thesis submitted in partial fulfillment of the requirements for the degree of

Master of Science Teaching

in

General Science

Thesis Committee:

William Becker, Chair Sybil Kelley

Stephanie Wagner

Portland State University

2013 
(C) 2013 Rachel Miriam Stagner 


\begin{abstract}
The goal of environmental education (EE) has always been to increase knowledge about the environment and to foster positive environmental attitudes. Increasingly, as the call for integrating EE programs into mainstream science curriculum intensifies, it is important to continue to evaluate the effectiveness of these programs not only through measures of change in knowledge and attitudes, but through the additional criteria of meeting the needs of different gender and ethnic groups.

The purpose of this research was to identify whether a watershed education program was meeting the needs of diverse learners within the context of a year-long, integrated, sixth-grade science curriculum. This study specifically sought to answer the following questions: 1) Do differences exist between genders and ethnic groups in regards to change in environmental knowledge after participation in an environmental education program? and 2) Do differences exist between genders and ethnic groups in regards to changes in environmental attitudes after participation in an environmental education program?
\end{abstract}

A mixed-methods approach consisting of a pre/post-test survey, interviews, and observational data was used to evaluate these questions. The quantitative results of the survey data suggests that, overall, students' had statistically significant $(p<0.01)$ gains in environmental knowledge, but no change in attitude towards the environment after participation in the program. When subpopulations are broken down into gender and ethnic groups, however, there is statistically significant support for the idea that ethnic groups--and, to a lesser extent, gender groups--were affected differently by the program. One important finding was that Hispanic and Native American students had 
significantly less gain in knowledge than their White, Asian and African-American peers. Qualitative interviews and observations shed light on these findings and illustrate the experiences of students during the year-long program. Other findings, trends, observations, and opportunities for future research are also discussed. 


\section{Dedication}

This thesis is dedicated first and foremost to the students, teachers, and educators who made this research possible. And also to friends, family, and loved ones who supported and loved me throughout my stint as a graduate student (and beyond). 


\section{Acknowledgements}

Special thanks to my thesis advisors, committee members, fellow researchers, and professors at PSU for their support and insight during this process: William Becker, Stephanie Wagner, Sybil Kelley, Deborah Barany, Jack Kirshenbaum, Rosalyn McKeown, and Julie Smith.

Extra special thanks to Rachel Felice and the "River School" program for participating in this research and allowing me access, feedback, and suggestions. Also to the "Rivergate" school district and "GWCS" middle school where this research was conducted.

Thanks to Gaylen Beatty for the use of her survey instrument and for answering questions about her study and results.

Finally, thanks to my fellow graduate students who were there to discuss findings, brainstorm ideas, provide suggestions, and lend a listening ear both before and after graduate school was over. 


\section{Table of Contents}

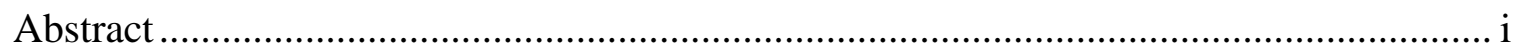

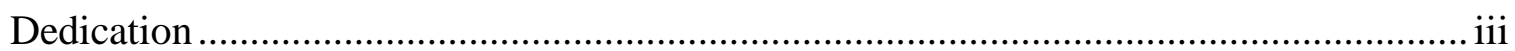

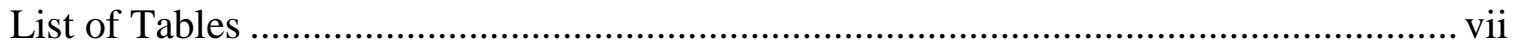

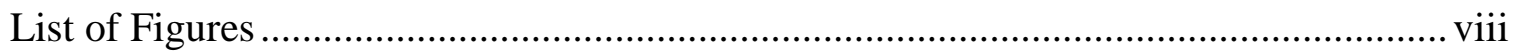

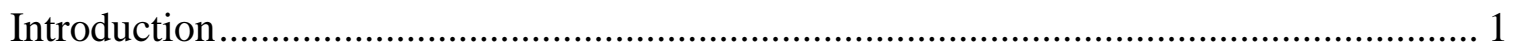

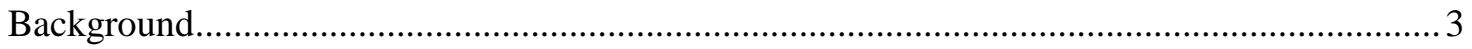

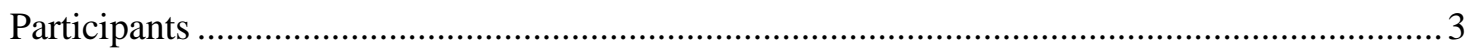

Rivergate School District/G.W. Carver School................................................................ 4

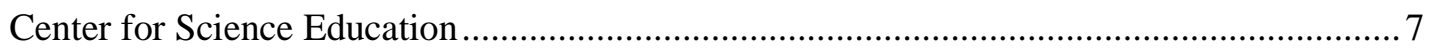

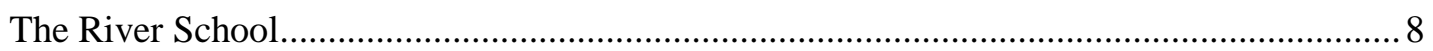

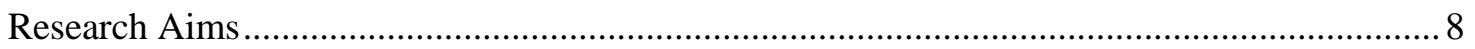

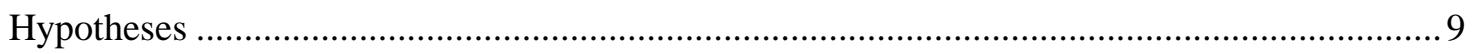

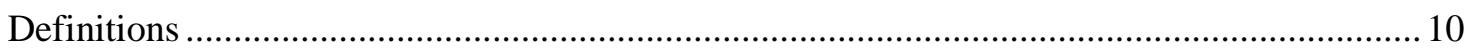

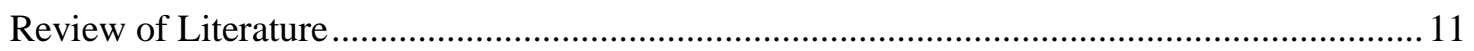

Environmental Knowledge and Attitudes .................................................................. 11

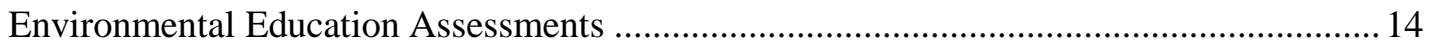

Gender and Ethnicity in Environmental Education........................................................ 16

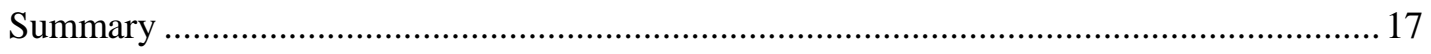

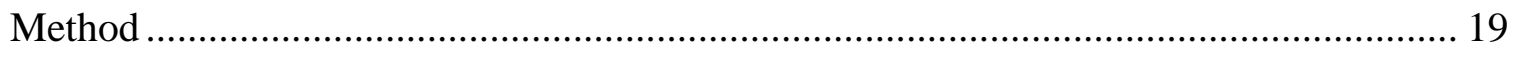

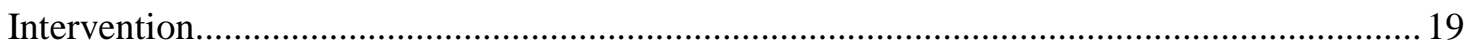

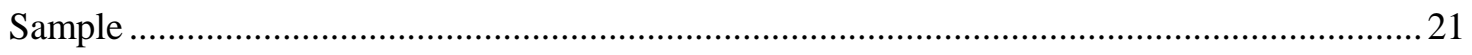


Instruments

Survey

Interviews .28

Observations 29

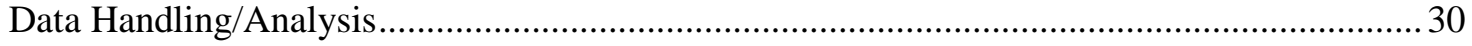

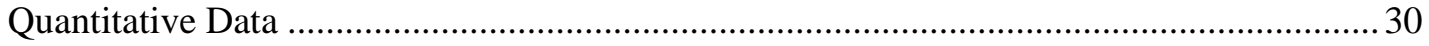

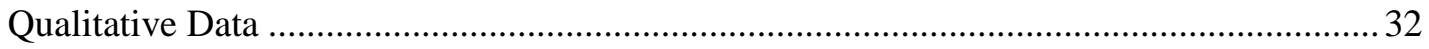

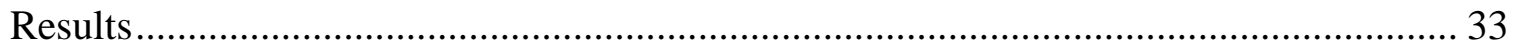

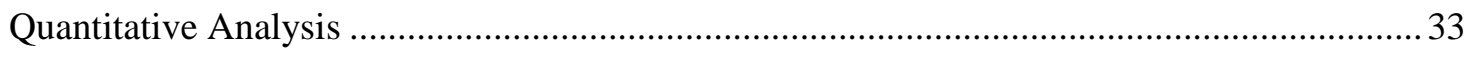

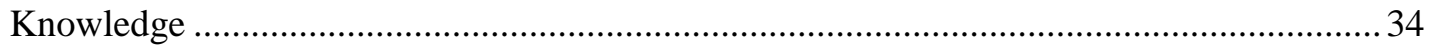

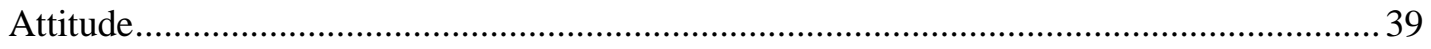

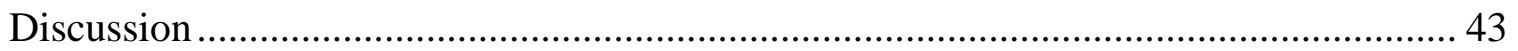

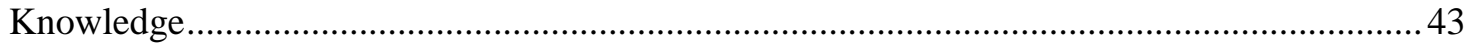

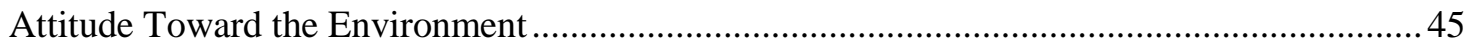

Knowledge and Attitudes Toward the Environment Taken Together .......................................48

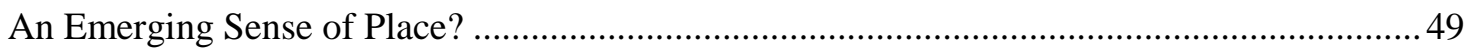

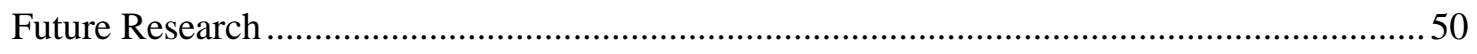

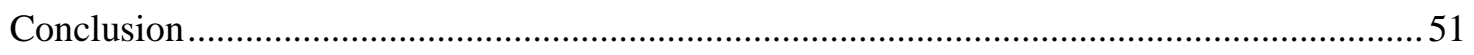

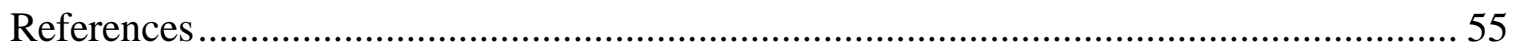

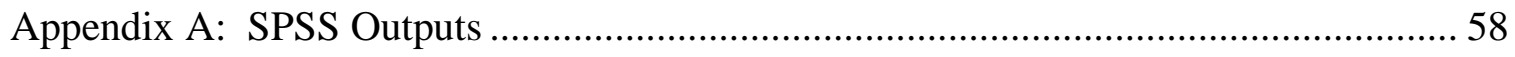

Appendix B: Learning Outcomes \& Coverage for River School Programming ............. 61

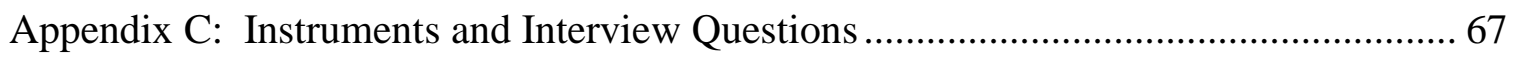




\section{List of Tables}

Table 1. Comparison of Demographic Information for the Rivergate School District and

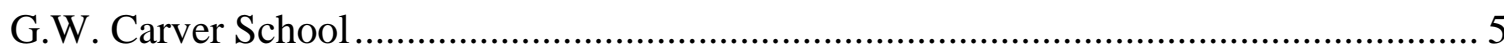

Table 2. River School Lesson Topics During the 2006-2007 School Year.................... 20

Table 3. Paired t-test Statistics for Major Variables and Questions With Significant

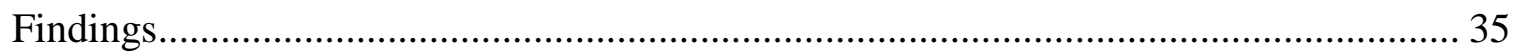

Table 4. Descriptive Statistics for Knowledge Scores .............................................. 38

Table 5. Descriptive Statistics for ATE ................................................................. 41 


\section{List of Figures}

Figure 1. Science Achievement Data for GWCS by Ethnic Group ................................... 8

Figure 2. A Model of ERB Developed By Hines, Hungerford, and Tomera (1987)....... 13

Figure 3. Comparison of pre- and posttest scores for EK and ATE ............................... 34

Figure 4. Percentage of Students Who Answered EK Question Two Correctly, Pre and

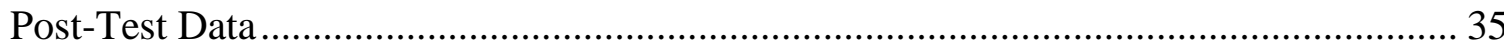

Figure 6. Pre- and Posttest Scores for Knowledge by Gender and Ethnicity * =

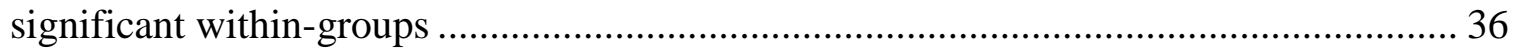

Figure 7. Pre- and Posttest Knowledge Scores for Ethnicity x Gender * = significant

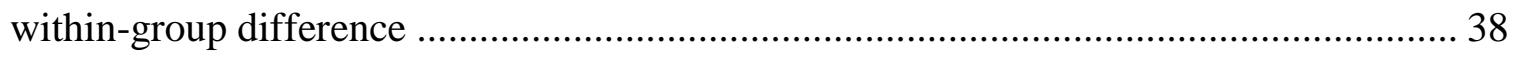
Figure 8.Percentages of Students' Responses to Question Three on the ATE Portion of

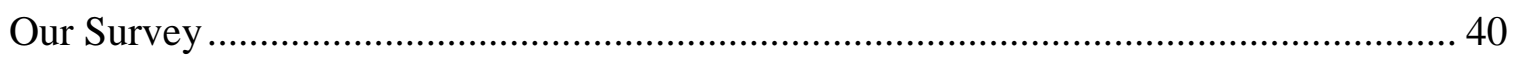

Figure 9. Pre- and Posttest Scores for ATE by Gendery and Ethnicity ........................... 42

Figure 10. Pre- and Posttest Scores for ITA by Gender and Ethnicity ............................ 42

Figure 11. Pre- and Posttest Scores for EA by Gender and Ethnicity ............................. 42 
Introduction

Environmental education (EE) is often regarded as the best way to ensure that the mistakes in judgment that have led to the current situation of environmental degradation on our planet are not repeated in future generations. Stapp et al., (1969) described the goal of EE as the production of future citizens who are capable of understanding the problems facing the biophysical environment, are aware of possible solutions to those problems, and are willing to work towards their solution. Ultimately, this goal involves changing people's behavior towards a more environmentally-friendly ideal.

Social research has suggested that in order to change people's behavior in a certain domain, it is necessary to first change their knowledge and attitudes towards that domain (Ajzen \& Fishbein, 1980). Support for this is also found in the field of EE, where positive correlations between environmental attitudes and environmental knowledge (Bradley, Waliczek, \& Zajicek, 1999), and between environmental attitudes, environmental knowledge, and environmentally-responsible behavior, (Meinhold \& Malkus, 2005), have been found. School-age youth are particularly targeted by EE as it has been suggested that children begin to develop attitudes toward the environment at a very young age (Bryant \& Hungerford, 1977).

To meet the pressing need for more EE in a increasingly environmentally challenged world, a multitude of private groups and organizations have sprung up with the goal of educating about environmental issues, positively impacting environmental attitudes, and encouraging environmentally responsible behaviors (ERB). Evaluating the effectiveness of EE programs is an important component of ensuring that these programs 
continue to meet their educational and other goals. Evaluation also provides valuable feedback which can, in turn, be used to continually refine and improve educational practices and these programs' impact on participants' attitudes toward the environment and their ERB (Leeming, 1997; Seacrest \& Herpel, 1997; Zint, Kraemer, Northway, \& Lim, 2002).

In the past, evaluations of EE programs included surveys given to participants in order to measure changes in knowledge and attitudes after the program was concluded. Significant changes in these measures were looked upon as proof of the EE program's effectiveness. There is a gap, however, in research and evaluation pertaining to EE programs that examines changes in knowledge and attitudes broken down by ethnic and gender groups. As the integration of EE programs into the regular science curriculum of schools is becoming more prevalent, more detailed evaluations are needed to assess their effectiveness within this new context. In an increasingly diverse public school system, it is important not only to evaluate how well EE programs increase environmental knowledge and attitudes, but how well they are serving students from different gender and ethnic groups. The research presented here begins to address this gap in knowledge by investigating the effects of a year-long environmental education intervention on the knowledge and attitudes of a diverse student body. 


\section{Background}

This study began in 2005 as a simple evaluation of a local EE program, The River School (RS) ${ }^{1}$. The River School is a non-profit, watershed education program that serves a population of school-age children in the Portland, Oregon, Metropolitan Area. The organization expressed interest in evaluating its educational programming in order to document positive changes in environmental knowledge and attitudes of students after participation in the program. As the details of the partnership between RS and the Center for Science Education (CSE) at Portland State University were ironed out, however, the opportunity arose to go beyond a simple evaluation of changes in environmental knowledge and attitudes and explore race and gender issues in EE. This opportunity materialized when RS was contracted to conduct a full-year intervention at a public school that served a diverse student body: the George Washington Carver School (GWCS). A new, three-way partnership between RS, CSE, and GWCS formed, and an evaluation that examined changes in environmental knowledge and attitude through the lenses of gender and ethnicity was proposed and adopted.

\section{Participants}

Sixth grade students at GWCS participated in this research. G.W. Carver School is an arts, science, and technology magnet school which had an existing partnership with

\footnotetext{
${ }^{1}$ Pseudonyms have been given to all place names, schools, districts, environmental education groups, teachers, and students mentioned in this study to protect confidentiality.
} 
CSE. The partnership between the two organizations was formed in order to aid the transition of the school into a magnet school and, specifically, to support the new science and technology focus at the school.

At the end of the 2005-2006 school year, the long-time sixth grade science teacher retired and was not replaced. Instead, the school administration utilized the partnership with the Center for Science Education to support science teaching at the sixth grade level, rather than re-hiring a new full-time science teacher. The researchers proposed an alternative method of science instruction to help address the achievement gap in science at the school by integrating local, place-based science instruction into the curriculum. Recent literature has supported this type of integration as a way to engage students in science and school in general (Disinger, 2001; Gruenewald, 2003; Lieberman \& Hoody, 1998; Smith, 2007; Volk \& Cheak, 2003). The researchers approached the River School, a local watershed education program, to provide this service to the sixth grade. GWCS, CSE, and RS reached an agreement to integrate locally relevant, environmental education into the sixth-grade science curriculum. This partnership allowed the researchers to evaluate the effectiveness of the RS program within the setting of an ethnically diverse public school. Rivergate School District/G.W. Carver School

A relatively few number of schools in the urban region of Northwest Oregon serve the majority of the metro-area's low-income and minority populations. These schools tend to be clustered in pockets throughout the region, and fall into several 
different school districts. The school in this study, G.W. Carver School, is located in the Rivergate School District, one of Oregon's largest school districts.

Rivergate School District (RSD) served 46,348 students in the 2006-07 school year. As shown in Table 1, of those 46,348 students, 55 percent were white, 16 percent African American, 14 percent Latino, 11 percent Asian, 2 percent Native American and 2 percent "other." At GWCS, the ratio of minority students looks much different. At Carver, only 26 percent of the students are white, 46 percent African American, 18 percent Latino, 8 percent Asian and 3 percent Native American. In addition, district wide, 45 percent of students are eligible for free or reduced lunch, whereas the GWCS population is 83 percent free and reduced lunch (District data, retrieved 3/23/08 and 10/01/06).

Students in all the sixth grade science classrooms at GWCS were invited to participate in this research. Thirty-seven students returned consent forms. Although these students exhibited many student characteristics, ethnicities, genders, challenges, interests, experiences, socio-cultural backgrounds, and science conceptions, the cohort Table 1. Comparison of Demographic Information for the Rivergate School District and G.W. Carver School

\begin{tabular}{|c|c|c|}
\hline 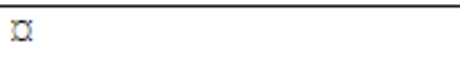 & \multicolumn{2}{|c|}{ Percento } \\
\hline$\alpha$ & Rivergate-School-Districto & G.W. Carver-Schoold \\
\hline Demographic-Breakdowno & $\alpha$ & $a$ \\
\hline African-American & $16 \%$ & $46 \%$ \\
\hline European-Americand & $55 \%$ & $26 \% 0$ \\
\hline Latinod & $14 \%$ & $18 \%$ \\
\hline Asiand & $11 \%$ & $8 \%$ \\
\hline Native-Americano & $2 \%$ & $2 \%$ \\
\hline Free/Reduced Luncho & $45 \%$ & $83 \% 0$ \\
\hline
\end{tabular}


students differ from the sixth grade student-body in a couple of striking categories (Table 2). Fewer than half of the African-American males returned informed consent forms. On the other hand, both male and female White students were represented in the cohort at a higher rate than in the grade as a whole -47 percent more White males than in the whole grade-level, and 41 percent more White females. Another difference was that Talented and Gifted (TAG) students were represented more than twice as much in the study cohort than the grade overall. Conversely, the Special Education (SPED) students in the cohort were represented 25 percent less than Special Education students in the whole group. Although these differences between the sample population and the gradelevel as a whole represent a limitation to our study, the participating students have

Table 2. 6th Grade Cohort Make-up, Compared to Whole

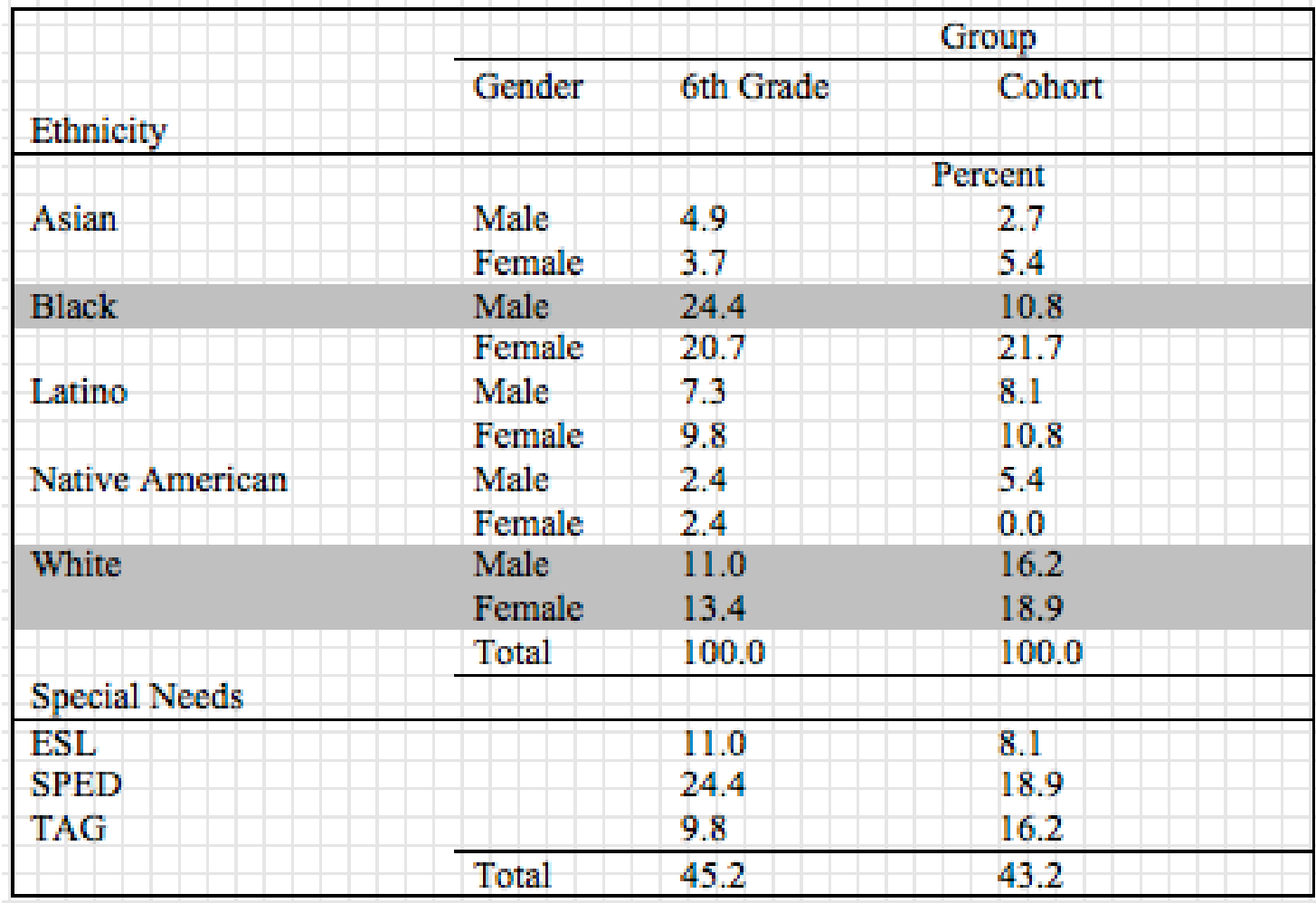


provided great insight into how the River School Program is meeting its objectives.

While science achievement at GWCS has increased for all ethnic groups over the past three years, the achievement gap between minority students and their white middle class peers remains significant. In the 2003-04 school year, 41 percent of white students met or exceeded standards in science, compared with 12 and 22 percent for African American and Hispanic students, respectively. In the 2005-06 school year, the percentage of white students meeting or exceeding standards rose to 65 percent, while the percentage for African American students only rose to 24 percent, and the percentage of Hispanic students actually dropped to 17 percent meeting or exceeding standards (Figure $1)$.

\section{Center for Science Education}

The mission of the Center for Science Education is to enhance science teaching and learning through innovative education, research, and community outreach programs. The Center promotes a constructivist model of science education that uses technology as a powerful tool to enhance science inquiry. In this model, teachers build learning activities around students' existing knowledge, skills and interests, and utilize the local environment as a context for integrating curriculum. Through its programs, CSE aims to help students and teachers raise their capacity to participate in the community as informed citizens. 
Figure 1. Science Achievement Data for GWCS by Ethnic Group

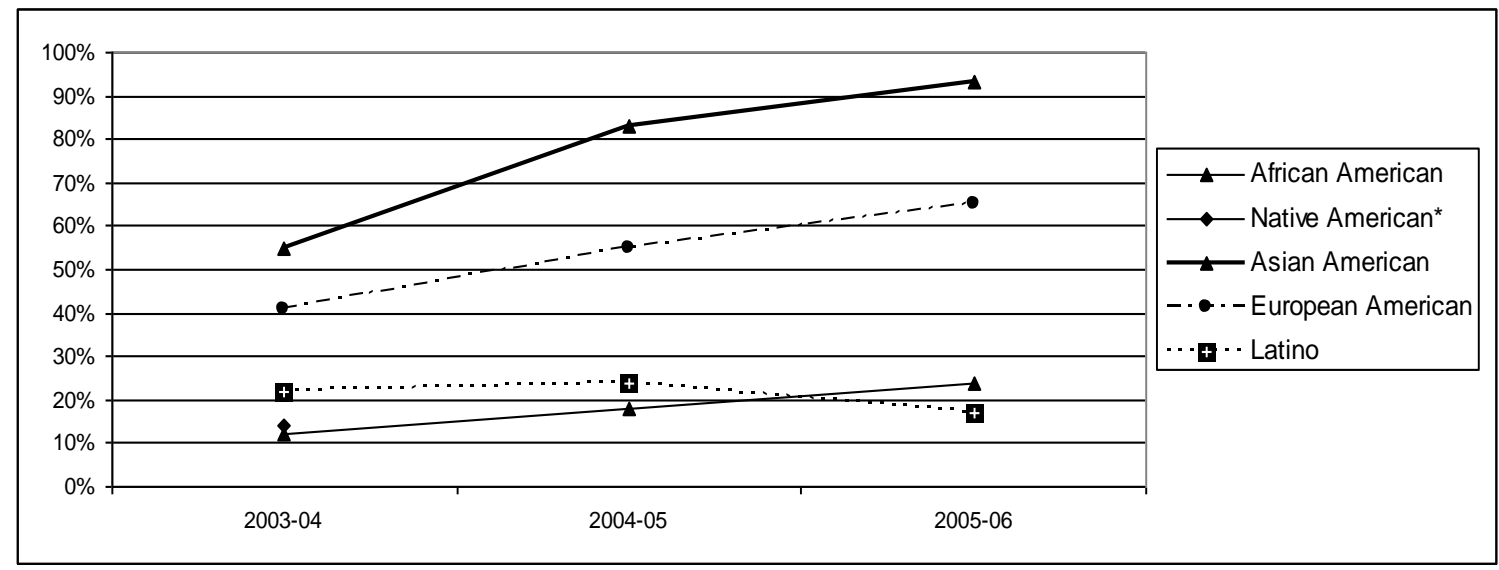

\section{The River School}

The River School is an educational program that serves schools and students within a local watershed. In existence since 2002, the program focuses on educating students about the history and ecology of the watershed and encouraging stewardship behavior. RS provides classroom, field, and summer camp opportunities to an estimated 5,000 students every year. A variety of educational courses teaching the biological, physical, and chemical properties of the watershed, as well as presenting current environmental issues surrounding the watershed, are offered to students from grades K12 through this program. The program emphasizes a variety of teaching techniques, but hands-on instruction and field trips are a large and important part of their teaching strategy.

\section{Research Aims}

The primary aim of this study was to determine whether the RS program was meeting its programmatic goals of increasing students' knowledge about their local watershed and positively affecting students' environmental attitudes. In addition, the 
researcher wished to examine whether gender and ethnicity affected how students responded to the program and whether differences in knowledge and attitudes existed between groups. It is assumed that information from this study will aid the River School program in improving their educational practices as well as provide direction for future studies that examine the interplay of ethnic and gender issues in environmental education.

Specifically, our research aims were as follows:

- To test whether students' knowledge of their local watershed and related science concepts increased after participating in the RS program

- To test students' Attitude Towards the Environment (ATE) and whether it changed as a result of participation in the RS program

- To explore whether differences in students' knowledge existed between genders and ethnic groups

- To explore whether differences in students' attitudes existed between genders and ethnic groups

\section{Hypotheses}

Based on my research aims, I formulated several hypotheses:

- Students' environmental knowledge will increase as a result of participation in the RS program.

- Students' ATE will increase as a result of participation in the RS program

- The RS program will affect students of different gender and ethnic groups differently in terms of their environmental knowledge (within-group effect) 
- The RS program will affect students of different gender and ethnic groups differently in terms of their ATE (within-group effect)

- Differences in environmental knowledge will be found between gender and ethnic groups (between-group effect)

- Differences in ATE will be found between gender and ethnic groups (betweengroup effect)

It should be noted that although RS aspired to affect all gender and ethnic groups in a similar fashion, for the purpose of this research and subsequent analysis, null hypothesis were selected that propose differences between groups.

\section{Definitions}

- Environmental Knowledge $(E K)$ is defined as students' score on a five-question, 10-point survey developed by the researcher that measures students' recall of concepts related to the RS program and its educational goals.

- Attitude Towards the Environment (ATE) is defined as students' caring about issues involving their local watershed and is specifically students' score on a 13point likert-scale survey developed by the researchers. It is additionally comprised of two subvariables of interest:

- Intent to Act (ITA) is defined as students' personal willingness to engage in activities which benefit the local watershed and the environment (questions 1-6)

- Environmental Attitude (EA) is defined as students' perceptions of the importance of watershed issues to themselves and others 
- Environmentally Responsible Behavior (ERB), while not directly measured by this study, is defined as actions that directly or indirectly benefit the environment

\section{Review of Literature}

\section{Environmental Knowledge and Attitudes}

Social research has indicated the importance of changing people's attitudes in a certain domain before you can expect to change their behavior (Ajzen \& Fishbein, 1980). Thus, it has been an important area of research in environmental education to demonstrate a relationship between participants' environmental knowledge (EK), environmental attitudes (EA), and their environmentally responsible behavior (ERB). The existing research provides a rationale for why many studies focus on measuring environmental knowledge and attitudes as an indicator of change in participants.

Arcury (1990) found a positive relationship between EK and EA through a telephone survey of participants conducted in Kentucky. This research used the New Environmental Paradigm attitude scale, (Dunlap \& Van Liere, 1978), and the General Environmental Knowledge Measure, (Arcury \& Johnson, 1987), to obtain scores for both environmental attitude and environmental knowledge for 680 adult participants. Pearson's $r$ correlations revealed a statistically significant, positive relationship between environmental knowledge and environmental attitudes of participants, indicating that people with a higher knowledge score also scored higher on the scale of environmental attitudes (Arcury, 1990).

This relationship between EK and EA has also been found in school-age children. Bradley, Waliczek, and Zajicek, (1999), tested high school students in Texas on an EK 
scale developed from a state environmental science course and a 15-point likert scale of EA questions gleaned from several sources. Using Pearson's $r$ as a measure of correlation, a statistically significant relationship was found between students' pretest knowledge scores and pretest attitude scores and between students' posttest knowledge scores and posttest attitude scores. As with Arcury's (1990) study, students' with higher knowledge scores also had higher attitude scores (Bradley, Waliczek, \& Zajicek, 1999).

Factors other than EK have also been suggested as important to forming positive attitudes towards the environment. Eagles \& Demare, (1999), surveyed 72 sixth-graders at an environmental camp in Ontario, Canada to determine their score on a survey based on Kellert's (1979) environmental attitude scale. Additionally, they asked students to indicate participation in several "environmental involvement" categories, which can arguably be classified as environmental behavior. Their research found through Pearson's $r$ correlations that a positive EA was associated with students' talking about the environment at home, watching nature films, and reading about the environment.

The relationship between EK, EA and how they lead to ERB is strengthened by several studies which examined the variables which influence ERB. In a meta-analysis of existing research Hines, Hungerford and Tomera (1987), examined variables directly correlated with ERB (which they called Responsible Environmental Behavior). They found correlations between EA and EK as precursors to ERB and proposed a model to 


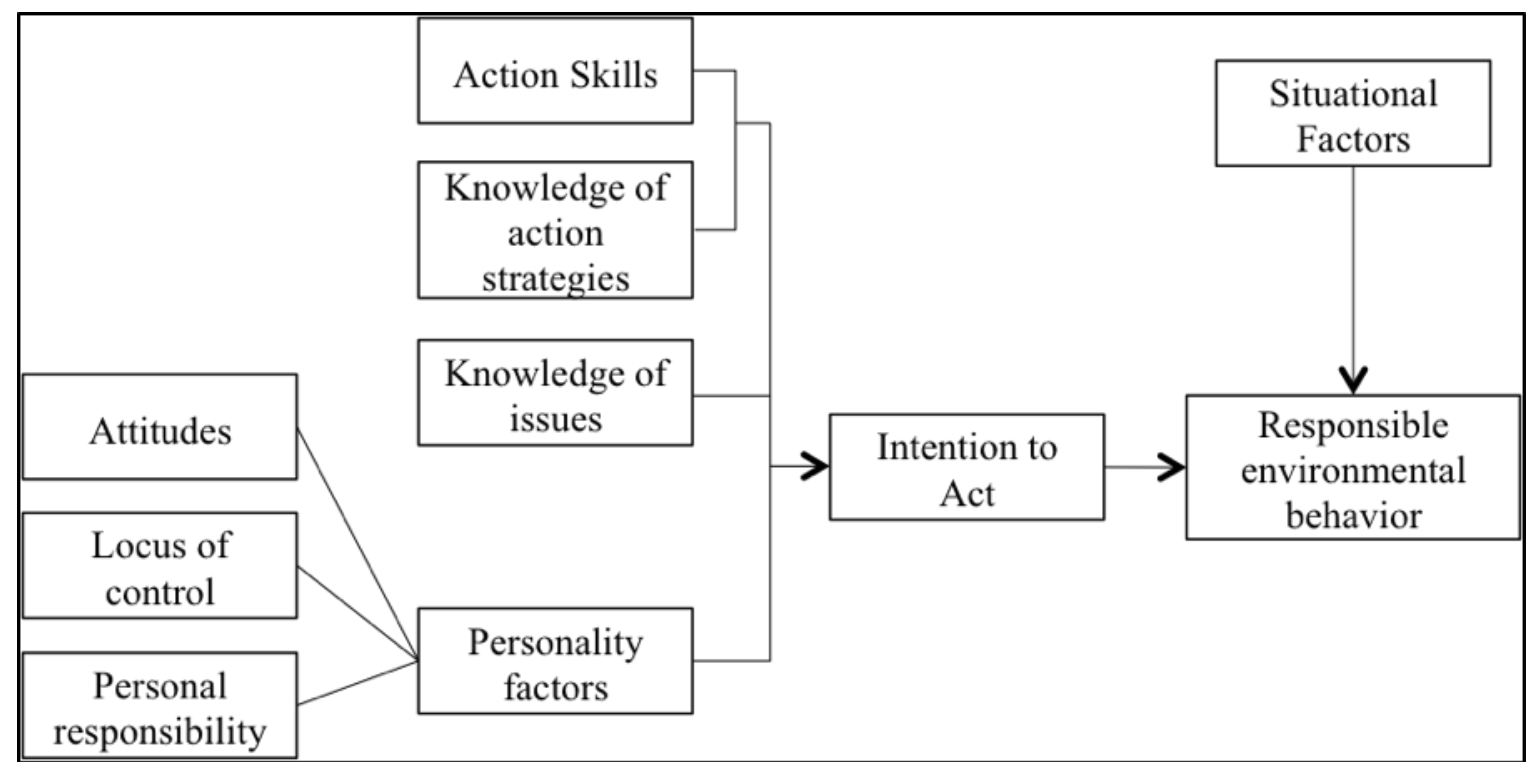

Figure 2. A Model of ERB Developed By Hines, Hungerford, and Tomera (1987).

explain the relationship between significant variables and ERB (Figure 2). An additional meta-analysis performed by Bamber and Moser in 2007 also found correlations between variables they identified as Problem Awareness, (arguably EK), Attitude and Intention as precursors to Behavior. Finally, Meinhold and Malkus (2005) surveyed 848 high-school students on the West Coast using a large 142 item survey to measure environmental knowledge, environmental attitudes, and ERB. They found a significant relationship between the three variables, with both pro-environmental attitudes and environmental knowledge being effective predictors of ERB (Meinhold \& Malkus, 2005).

Overall, trends in research suggest it is necessary to change people's attitudes and knowledge about the environment before expecting a change in ERB. While knowledge and attitude are not the only precursors to ERB (Bamberg \& Moser, 2007; Hines, Hungerford, \& Tomera, 1987), they are the most commonly assessed variables that are known to contribute to it. Since one of the primary goals of environmental education is 
to encourage ERB in participants, it makes sense to measure environmental knowledge

and attitudes in order to document success of the environmental education program.

\section{Environmental Education Assessments}

Several studies on the effects of environmental education programs on participants' environmental knowledge and attitudes have been conducted. A selection of these studies has provided a framework of reference for the design and implementation of this study.

A study by Leeming (1997) examined elementary students (grades K-6) from 19 schools in the Southeastern United States who were exposed to a year-long intervention of environmental interventions collectively called the Caretaker Classroom Program. Teachers picked a minimum of eight environmental activities from a menu of choices, including things such as recycling, planting trees and flowers, etc. The researchers measured students' pre- and posttest environmental attitudes and knowledge using the Children's Environmental Attitude and Knowledge Scale, or CHEAKS (Leeming, Dwyer, \& Bracken, 1995). The results of this study indicated that students' knowledge score on the CHEAKS did not significantly change, while their environmental attitude increased (Leeming, 1997). Despite the similarities in context between this study and our own, however, an important issue was that students were tested on a general scale of knowledge and attitude, not one that was specifically tailored to the curriculum being presented, a shortcoming also admitted by the authors.

Zint, et al., (2001), undertook an evaluation of the Chesapeake Bay Foundation's conservation education programs in 1998. The Chesapeake Bay Foundation (CBF) 
conducts several workshops, camps, and short classroom interventions designed for school-aged youth. Zint el al. developed a survey instrument that was specific to the program's knowledge and attitude goals to measure changes in environmental knowledge, environmental attitudes (including Intent to Act), and Environmentally Responsible Behavior. In a separate study, they reported their results of administering the survey pre and post-program and also several months after the program's end to measure retention in 3,403 students (Kraemer, Zint, \& Northway, 1999). Their results indicated positive change in environmental knowledge and attitudes after participation in the CBF programming. Additionally, because Zint, et al. tailored their instrument to the CBF's goals, they were able to give specific recommendations to the program beyond just general trends in participants.

Beatty (2007) conducted an assessment of a local watershed education group in the same metropolitan area as the current study. Using the desired outcomes of the EE program as well as other assessments as a guide, including Zint et al. (2001) and Seacrest \& Herpel (1997), she developed a survey which measured student's environmental knowledge and Attitude towards the Environment (as defined by the current study). Included in the ATE measurement were the two sub-variables of interest in this study, Environmental Attitudes and Intent to Act. The survey was given pre and post-program to 228 students who participated in a classroom-based lesson on an aspect of watershed education. Her results indicated that students' knowledge and ITA increased significantly, while EA did not (Beatty, 2007). The local basis of this assessment as well 
as the similar educational and attitude goals of the two watershed education programs made Beatty's study a logical foundation on which to base the current study.

\section{Gender and Ethnicity in Environmental Education}

Many studies have been conducted on how gender and ethnicity impact traditional science achievement and highlight the importance of addressing cultural and gender concerns in science education (Heard \& Cantu-Mireles, 1995; Norman, Ault, Bentz, \& Meskimen, 2001; Rodriguez, 1998; Shroyer, Backe, \& Powell, 1995). However, research in gender differences in EE has often been inconclusive (Carrier, 2007; Zelezny, Chua, \& Aldrich, 2000). For instance, Zelezny, Chua, and Alrich (2000) found in their review of research concerning gender differences in environmentalism that females had stronger environmental attitudes and behaviors than men. However, in a study of fourth and fifth graders Carrier (2007) found no differences between genders in environmental attitude. Likewise, other studies have reported differences between genders in environmental knowledge, but the results are also often inconsistent (Carrier, 2007; Tikka, Kuitunen, \& Tynys, 2000). Research focusing on ethnicity in EE, on the other hand is scarce. While some studies have called for a more multicultural scope for environmental education (Cole, 2007; Marouli, 2002), research specifically addressing how different cultural groups respond to EE programs are rare. This kind of research is important not only to ensure that EE programs are serving the needs of an increasingly diverse constituency, but to provide evidence to educators and administrators that EE can enable students of many different backgrounds to engage in science and increase achievement. This is crucial in the current school environment, where high-stakes testing is increasingly 
pushing out alternative methods of teaching and learning, such as the participation in EE programs, despite the need for more student-centered, place-based education (Gruenewald \& Manteaw, 2007).

\section{Summary}

To summarize, research has found links between Environmental Attitudes, Environmental Knowledge, and Intent to Act as precursors to a person's Environmentally Responsible Behavior (Bamberg \& Moser, 2007; Hines, Hungerford, \& Tomera, 1987). Since a reasonable and oft-stated goal of environmental education programs is to change the ERB of participants, it makes sense to measure these variables as a way to measure the effectiveness of EE programs. There is also precedent in creating a new survey instrument to adequately assess an EE program (Beatty, 2007; Zint, Kraemer, Northway, \& Lim, 2002) which will be discussed in more detail in the method section of this report.

Additionally, while there is some research on the effects of gender on EE participant outcomes (Carrier, 2007; Tikka, Kuitunen, \& Tynys, 2000; Zelezny, Chua, \& Aldrich, 2000), there is very little research on the effects of ethnicity on outcomes, and even less on the combined effects of gender and ethnicity. As the population of United States becomes more ethnically diverse, it is critical that the effectiveness of EE programs on reaching all demographic groups is measured and used to improve outcomes for all. This will ensure that EE programs remain viable and relevant options to traditional curriculum in schools and continue to serve the local communities in which they reside. 
Within this context, our study sought to evaluate the RS program in terms of its effect on EK and EA of participating students at GCMS. Additionally, to begin to address the gap in knowledge in how students from different ethnic and gender groups respond to EE programs, we examined changes in EK and EA through the lens of gender and ethnicity. 


\section{Method}

\section{Intervention}

During the 2006-2007 school year, the RS educator gave 12 in-class presentations on a variety of topics and students attended four field trips which took place at the RS outdoor educational facility. Classroom visits were each approximately one hour and covered a range of topics designed to engage students in a study of the watershed. Lesson topics were selected to give students a broad overview of their watershed and the ecological and human influences that shape it. Example topics included "What is a Watershed?" "Water Chemistry," and "Animal Adaptations." Other lesson topics are shown in Table 3. In addition to the 12 classroom visits, four field trips were planned to reinforce students' knowledge of watershed issues and give them hands-on experience with things such as measuring water chemistry, catching, identifying, and categorizing macroinvertebrates to assess water quality, and identifying native vegetation.

In order to investigate whether the RS program was meeting its goals of increasing students' environmental knowledge and positively affecting attitudes toward the environment, a mixed-methods approach comprised of both positivist (a survey) and interpretive (focus-group interviews) components was utilized. Specifically, Creswell, as quoted in Fraenkel \& Wallen, (2006), defines this type of study as a triangulation design. Triangulation designs consist of research where both qualitative and quantitative data are collected simultaneous in order to validate each 
Table 2. River School Lesson Topics During the 2006-2007 School Year

\begin{tabular}{lc}
\hline & Topics \\
\hline "What is a Watershed?" & "Animal Adaptations" \\
"The Water Cycle" & "Bird Migration" \\
"Riparian Plants" & "Fish Biology" \\
"Who Polluted the xxxx?" & "Wetland Introduction" \\
"Water Chemistry" & "Wetland Plants" \\
"Macroinvertebrates" & "Ethnobotany" \\
\hline
\end{tabular}

other. This approach was chosen in order obtain a broad view of how students were affected by their participation in the RS program.

The quantitative (positivist) portion of this research design is best summarized by a one-group pretest-posttest design (Fraenkel \& Wallen, 2006). This quasi-experimental design methodology requires the same survey be given to students both before and after the intervention. The explicit assumptions of the design are that changes in student knowledge and attitude can be measured by comparing the pretest and posttest results and that any differences found are due to the intervention of the RS program. Thus, the pretest results serve as the control against which the intervention is measured. This methodology was chosen as the best way to document changes in knowledge and attitude since a traditional control or comparison was unavailable.

The qualitative portion of this research was composed of several parts: focus group interviews with students at the conclusion of the RS program, one-on-one interviews with participating teachers at the conclusion of the program, two e-mail interviews with the RS educator before and after the RS intervention, and written observations taken during the RS sessions. Our goal was to gain a better understanding of whether the various individuals involved in the program perceived differences in 
knowledge and ATE and to compare these perceptions with the results of the survey analysis.

\section{Sample}

The sixth graders at GWCS were randomly divided into three classroom periods of science by the school district. With few exceptions, most students stayed with their intact group throughout the entire school year. All three periods were subject to the same schedule of classroom visits by RS and had the same science curriculum over the entire year. Overall, 67 sixth graders participated in the year-long intervention and took both the pre- and post-tests.

As mentioned in the previous section, a traditional control group was not available for comparison in this study, since the environmental program was integrated into the curriculum and all students were exposed to it. The assumption of the teachers and researchers was that the environmental education program would benefit all students, and, thus, it would have been inappropriate and unethical to exclude some students from the experiences involved.

Informed consent forms were distributed to all students and 37 were returned. Of these, 32 students had completed both pre- and posttests. Thus, the final sample size for our study is 32 students. Of these students, 21 were interviewed in focus groups at the conclusion of the RS program. 


\section{Instruments}

Survey

Several instruments exist to measure environmental knowledge and environmental attitudes. When the opportunity to evaluate RS arose, the researchers performed a review of existing instruments to evaluate their possible use in this study.

One popular instrument is the Children's Environmental Attitude and Knowledge Scale, or CHEAKS (Leeming, Dwyer, \& Bracken, 1995). Despite the claim of the authors that this instrument has a wide applicability to a variety of studies, we found it to be too broad in scope, and had few questions related to water issues. Taskin, (2003), also criticized the CHEAKS assessment for researcher bias and the emphasis on rote memorization instead of critical thinking. Another instrument, The Children's Attitudes toward the Environment Scale, (Musser \& Malkus, 1994), likewise was too global in its evaluation of EA and didn't connect with RS's emphasis on place-based learning outcomes. Finally, the New Environmental Paradigm Scale, (La Trobe \& Acott, 2000), which measures EA, is also too broad in scope, too long in length, and not in childfriendly language - all factors that ruled out its use in this study.

After reviewing the existing instruments and finding them, in general, to be too broad and not connected with the learning goals outlined by RS, we made a decision to create a new instrument. Taskin's paper on the ignored facets of EA and EK scales suggested a route for development of a new instrument: 1) Support content validity of the instrument, 2) choose questions carefully both linguistically and conceptually, and 3) clarify the connections of questions to the outcomes of RS's program (Taskin, 2003). 
The final instrument consisted of a short, one-page survey. Briefness was considered essential to ensure that students were able to complete the survey in one class period and for age and cognitive development appropriateness, as suggested by previous studies (Musser \& Malkus, 1994; Taskin, 2003). The front page of the survey consisted of five questions designed to evaluate students' environmental knowledge, while the back page consisted of 13 likert-scale questions designed to measure students' ATE. More details of the construction of the different sections of the survey are found below.

Knowledge. The researchers wished to gain an understanding of how environmental knowledge specific to the RS program increased after a year-long intervention. Thus, we developed the knowledge portion of the survey with an eye to backwards design, an idea that encourages educators to align curriculum and assessment with specific learning outcomes (Wiggins \& McTighe, 2001). We began the process by examining RS's lesson plans which identified the major learning outcomes for each lesson. In addition, several discussions took place with the RS educator to determine which "enduring understandings" she wished students to retain at the end of the year-long intervention $^{2}$. Finally, a mixture of question-types (multiple choice, short-answer, and longer-answer) was used to engage multiple levels of cognitive functioning in students using the revised Bloom's Taxonomy as a guide as to wording and format of questions

\footnotetext{
${ }^{2}$ Enduring understandings are defined as the "big ideas, the important understanding, that we want students to 'get inside of' and retain after they've forgotten many of the details (p. 10)" (Wiggins \& McTighe, 2001).
} 
(Airasian et al., 2001). The final version of the survey contained five questions related to EK: one multiple choice, one short-answer, and three longer-answer questions. In order to ensure that the curriculum adequately covered the desired enduring understandings that were used to create the knowledge portion of the survey, the researcher matched the lessons that specifically targeted the desired outcomes and estimated the amount of instructional time. Appendix B shows a breakdown by category of the identified enduring understandings, the amount of time that was spent on each, and which questions on the survey assessed learning in that category. In order to estimate the depth of coverage of each learning objective within the broad categories, I examined the curriculum and class observation notes to estimate the amount of time spent on each topic. I created a scale from $0-4$ to classify the time (t), in hours, of coverage of individual topics where 0 is "not covered," (t=0); 1 is "briefly covered," $(0 \mathrm{~h}<\mathrm{t}<2 \mathrm{~h}) ; 2$ is "moderately covered," $(2 \mathrm{~h}<\mathrm{t}<5 \mathrm{~h})$; 3 is "heavily covered," $(5 \mathrm{~h}<\mathrm{t}<8 \mathrm{~h})$; and 4 is "intensively covered," $(\mathrm{t}>8 \mathrm{~h})$. Also presented is the median change in scores for each item on the knowledge portion of the survey as well as the total median EA change (sum of items 1-13, excluding 7).

Attitudes. The questions used for the ATE portion of the survey were only slightly modified from a similar assessment conducted on another local watershed education program (Beatty, 2007). Beatty, in turn, used questions adopted primarily from the Chesapeake Bay Foundation Education Program Evaluation (Kraemer, Zint, \& Northway, 1999). They also fit Aiken's criteria of being short, simple, and easy to understand (Aiken, 1996). In addition to these reasons, Beatty's survey was chosen as a 
guide because her study was conducted within the same city and evaluated a similar local watershed education program. Minor revisions, however, were made to Beatty's questions based on relevance to the current study. An example of a modification of the survey was the omission of the question "The Williamson River is cleaner than it was 50 years ago," from our survey because the RS program does not educate students on this body of water, and thus the question was irrelevant.

The second page of the survey measured students' ATE through the use of 13, five-point likert-scale questions. This portion of the survey was additionally broken up into two sub-variables of interest: Intent to Act (ITA) and Environmental Attitude (EA). Before the data were analyzed, test scores were normalized so each question had a positive answer with a point value of five. This led to a total ATE score of 60, of which 30 points were ITA and 30 points were EA.

The likert-scale for ITA consisted of six questions and had choices ranging from one to five, with one being "Very unlikely," two being "Unlikely," three being "Likely," four being "Very likely," and five being "Definitely." By design, there is no true neutral response in the ITA portion of the attitude survey; thus, a total ITA score of 0-12 represents a more negative ITA, and a score of 13-30 a more positive ITA. However, we did assume that scores nearer to the transition point (i.e. 12,13) signify more neutrality than those at the extremes.

The likert-scale for EA originally consisted of seven questions, however, the researchers decided to exclude question seven ("I think rivers and streams in our city are polluted") from analysis. Rivers in our city are still somewhat polluted, but have 
improved over the past several years. Thus, the researchers could not agree on which answer students could give that would be considered a "positive" response. Would recognizing that rivers were still somewhat polluted be a positive response? Or would saying that they are not polluted because they are improving be a better response? Since the researchers themselves could not agree on what constituted a positive response, it was logical to exclude this question from the final analysis.

Each question also had choices from one to five, with one being "Strongly disagree, two being "Disagree," three being "Neither agree nor disagree," four being "Agree," and five being "Strongly agree." A neutral answer of three "neither agree nor disagree" was available in the EA portion, thus a total score of 18 indicated a neutral EA, below 18 a more negative EA and above 18 a more positive EA. Overall, then a total ATE score of 0-30 was considered a negative ATE and 31-60 a positive ATE with scores near the transition point being more neutral than those at the extremes.

Pilot testing. To ensure that the final survey was understandable to students, a pilot-test was arranged during August of 2006. The survey was given to a small ( 15) group of students attending a one-day environmental workshop given by the RS educator. This pilot was done with middle-school aged children of mixed ethnicity similar to that of the school where research took place. The students were asked to take the survey and identify any questions that were not clear or words that they did not understand. None of the children involved reported any difficulty understanding the questions or taking the survey, and, therefore, no further modifications to the instrument were made. 
Reliability. To determine how internally consistent or "reliable" our attitude survey was, a Cronbach's Alpha Reliability test was run on the pretest data in SPSS. Cronbach's Alpha for the overall ATE (questions 1-13) was $0.807,0.771$ for ITA (questions 1-6), and 0.676 for EA (questions 7-10). Sources suggest that a minimum alpha of 0.70 is acceptable for social science research, while an alpha of 0.80 is excellent (Garson, 2008; Simon, 2004). Accepting these benchmarks, our overall ATE survey would fall into the excellent category, the ITA portion would be below acceptable, and the EA portion would be good. However, it should be noted that the low number of items in both the ITA and EA sections of our survey may have more to do with the low individual section alphas than the consistency of the measure (Garson, 2008; Nunnally, 1978).

Final implementation. Since the River School program was integrated into the sixth grade curriculum, both the pretest and posttest survey was given to all students, although only data from students that provided signed consent forms are included in this report. The pretest survey was given to students immediately prior to the first in-class session, and the posttest survey was administered four days after the last field trip experience and the conclusion of the RS program. The lead author administered the survey both times and developed a script to read aloud to students before the survey to ensure consistency. In this script, the researcher informed students that the survey was not a test, and thus was not graded, but that it should be taken seriously and completed without help. After instructions were given, an overhead of the survey was placed on a large screen in front of the classroom and the questions were read aloud to the students. 
Students were given as much time as they needed to complete the survey. A copy of the survey is included in Appendix C.

\section{Interviews}

Approximately one week after the posttest and two weeks after the final field experience, four focus groups were held with groups of four to five students each and conducted by two researchers. The total number of students interviewed was 21 . Each interview was conducted in a semi-structured format, with researchers asking each group of students several set questions in order to elicit responses about how the RS program affected their learning and attitudes. One question asked "Thinking about River School, what did you learn from those experiences - the classroom visits and the field trips?" Similar questions were posed to examine how they best learn science, which lessons they thought were most and least effective in their learning, and if how they thought of their local environment had changed. In addition to the set questions, researchers asked additional questions as needed to clarify student responses. Lastly, students were informed that their answers would be kept anonymous. All focus group sessions were audio taped and later transcribed. A copy of the interview questions is included in Appendix C.

In addition to talking with students, the two classroom teachers that hosted the program throughout the year and the educator from the River School were interviewed to gain their perspectives on the effectiveness of the program and specific lessons, as well as any evidence they could provide relating to changes in student knowledge or attitudes. Questions with the two classroom teachers were developed prior to the interviews, which 
were audiotaped and transcribed. Questions were similar to those given to students, and included such topics as which lessons they found most and least effective, and questions designed to determine if the teacher felt that the program benefited any ethnic or gender group more than the others. Finally, a written set of interview questions was emailed to the RS educator both before and after the year-long intervention to identify such things as what her goals for the year were, what things she anticipated being challenging, final impressions of how well the year went, and which lessons she felt were most and least successful.

\section{Observations}

The researchers in this study were present for all of the in-class lessons and the field trips. This type of participant observation allowed us to see how lessons were progressing and to get to know the students, teachers, and the RS educator during the course of the intervention. Reflective notes written during and after in-class sessions and field trips provided a further source of qualitative data from which to gain perspective and context in this study. Examples of things we documented were whether students seemed engaged or bored, how much students interacted with the RS educator, and students' general mood and motivation.

In addition to notes taken during class time and field trips, three official observations were conducted on three different lessons during the school year. These lessons were "The Water Cycle," which consisted of a short PowerPoint lecture and most time spent on a hands-on, interactive game where students were allowed to move about the classroom collecting beads at different stations; "Ethnobotany," which consisted of 
half of the time listening/watching a PowerPoint lecture and half the time passing around/examining items used by indigenous people; and finally "Bird Migration," which was primarily a PowerPoint presentation with a short worksheet activity. Thus, the three class-sessions where official observations were taken spanned a range of pedagogical approaches to student learning: mostly hands-on, a mixture of lecture and hands-on, and mostly lecture.

Each of the official observation periods consisted of the researcher sitting in the back of the room and not interacting with students. The researcher used form that was developed prior to the observations consisting of open ended questions and likert-scale items and focused on A) Educational Goals and B) Student Interactions (Appendix C). The purpose of this form was to quantify the overall effectiveness of the lesson and provide three objective benchmarks throughout the year.

In the educational goals section of the form, the researcher noted the learning goals of the class, the incorporation of the goals into the presentation, and whether or not the knowledge was clearly imparted during the class session. In part II, student interactions, the researcher used a likert scale ranging from $1-4$ (strongly disagree to strongly agree) to rate whether students seemed interested in the subject matter, were paying attention, and interacted with the educator when requested.

\section{Data Handling/Analysis}

\section{Quantitative Data}

After all the posttests were collected, they were paired with the pretests and any unmatched pairs were not included in analysis. The total number of students who 
completed both pre- and post-tests is 67 . The final sample size for students who provided consent and had taken both pre- and posttests is 32 .

The surveys were scored with a previously developed key, and separate scores obtained for knowledge and attitudes. All scoring was done by the researcher in order to ensure consistency. Gender and ethnicity of participants were obtained from school demographic information.

Knowledge. The knowledge section of the pre- and posttests was scored according to a key which assigned a set number of points to each question based on its format. For example, the first question was a multiple choice question ("What is a watershed?"), and thus the correct answer was given one point, and an incorrect answer was given a score of zero points. Open-ended questions such as question four (List three native plants and animals that live in this area) were given point values based on the completeness of the answer (three point maximum, one for each native plant or animal named, zero points for a wrong or no answer). Blank answers for all knowledge questions were given a score of zero. Individual point values for each knowledge question were imputed in SPSS and a total knowledge score was obtained by summing students' scores for questions one through five.

Attitude. The data from the second page of the survey, which measured students' Attitude Towards the Environment (ATE) through the two sub-variables Intent to Act (ITA) and Environmental Attitude (EA), were also entered into SPSS. Individual questions, ITA (questions 1-6), EA (questions 8-13), and a total score (all items) were analyzed. During all analyses of the attitude portion of the survey, questions that were 
left blank were excluded from analysis. Scores were input into SPSS, and data normalized so positive responses were worth five total points, and negative responses were worth one point.

Analysis. SPSS was used to input and analyze the results of the survey and ascertain if any differences in knowledge and/or attitudes existed between genders and ethnic groups. After all data was entered in SPSS, a professional statistician was consulted and a methodology developed to analyze the survey results. Statistical methods included two-way within-subjects analysis of variance and paired t-tests, and are covered further in the results section of this paper.

\section{Qualitative Data}

Qualitative data consisted of focus group interviews with students, teacher and educator interviews, and written observations. All interviews were transcribed from taped recordings. After the quantitative portion of the analysis was completed, the qualitative data were examined to gain a clearer understanding of our results 
Results

\section{Quantitative Analysis}

A two-way within-subjects analysis of variance (ANOVA) was conducted to evaluate the effect of gender and ethnicity on pre- and posttest knowledge, ITA, EA, and ATE. The dependent variables were the separate knowledge, ITA, EA, and ATE scores and the within-subjects factors were Time with two levels (pre- and posttest), Gender with two levels (male, female), and Ethnicity with three levels (Hispanic/Native American, African-American, and White/Asian). ${ }^{3}$ The Time, Gender, and Ethnicity main effects and Time x Gender, Time x Ethnicity, and Time x Gender x Ethnicity interaction effects were tested using the multivariate criterion of Wilks's lambda $(\Lambda)$ for each dependent variable of Time, ITA, EA, and ATE. On all statistical tests, a 0.05 level was selected to indicate significance.

An additional one-way ANOVA was conducted to evaluate the relationship between gender and ethnicity and the change in knowledge and attitude (ITA, EA, and ATE). The independent variables were gender with two levels: male and female and ethnicity with three levels: Hispanic/Native American, African-American, and

\footnotetext{
${ }^{3}$ For the purpose of this analysis, ethnic groups were paired due to low numbers in both the Asian and Native American categories, which would have rendered statistical tests useless. Upon review of the science achievement data for GWCS, it was decided that it made more sense to pair Hispanics with Native Americans and Asians with Whites based on their science achievement (please see Figure 1). From a cultural perspective this also fit better than pairing, for instance, Asians with African-American students.
} 
White/Asian. Again, a 0.05 level was selected to indicate significance. SPSS output tables for within and between group effects can be found at the end of this paper in Appendix A.

As a measure of effect size, Cohen's $d$ measure of power was calculated for each ANOVA interaction of variables. According to Coe (2002), effect size is "a standardized, scale-free measurement of the relative size of the effect of an intervention (p. 15)." Thus, it provides a measure of how much students' scores on each measured variable changed. In this study Cohen's d values were categorized as having a small effect at $d=0.2$, medium effect at $d=0.5$, and large effect at $d=0.8$, in accordance with accepted values (Coe, 2002).

\section{Knowledge}

Overall, student knowledge increased 25 percent after exposure to the RS intervention, with a mean increase of 2.5 points (Table 4;Figure 3). A paired t-test of the pre- and posttest scores showed this increase to be significant, $t(31)=-5.568, p<0.001$.
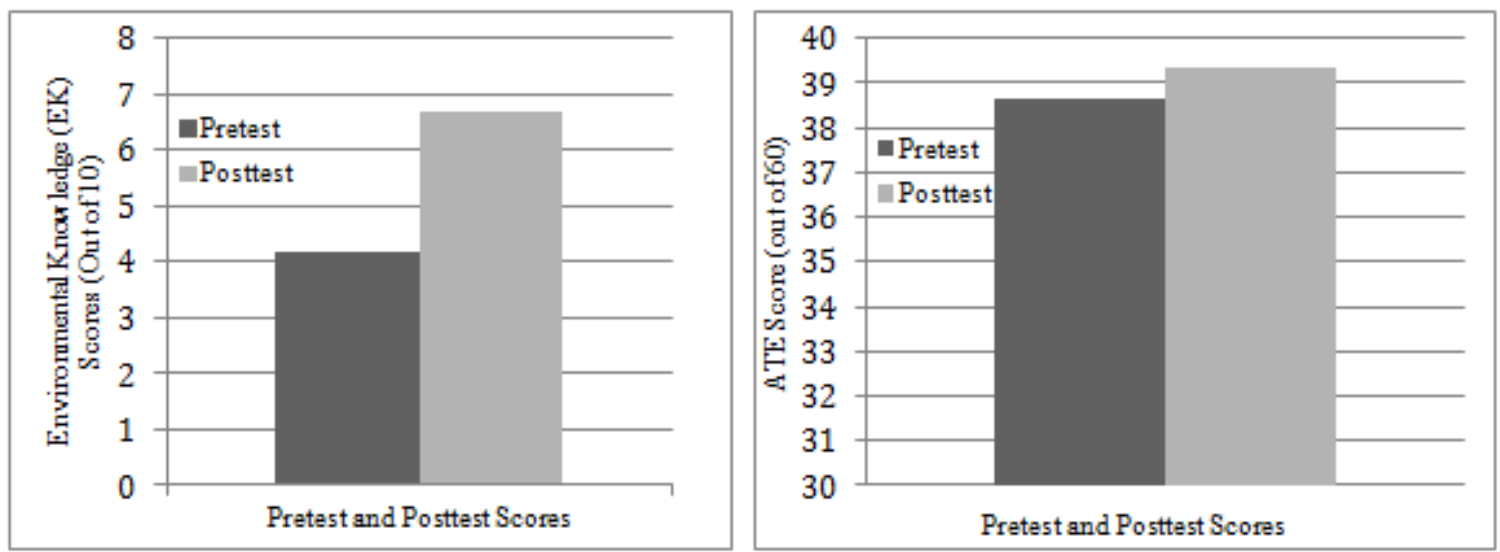

Figure 3. Comparison of pre- and posttest scores for EK and ATE 


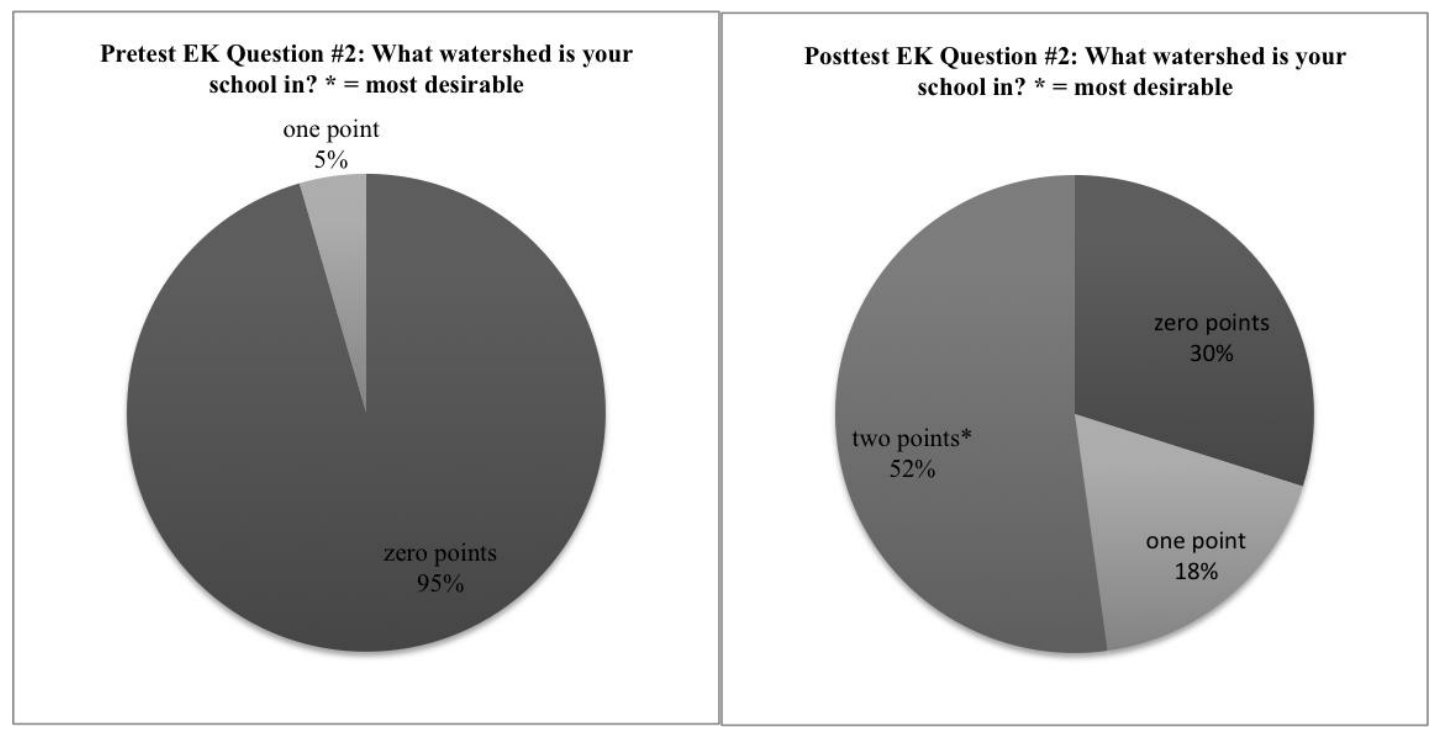

Figure 4. Percentage of Students Who Answered EK Question Two Correctly, Pre and Post-Test Data

Table 3. Paired t-test Statistics for Major Variables and Questions With Significant Findings

\begin{tabular}{|c|c|c|c|c|c|c|c|c|}
\hline \multirow[b]{3}{*}{ Variable } & \multicolumn{5}{|c|}{ Paired Differences (Posttest - Pretest) } & \multirow[b]{3}{*}{$\mathrm{t}$} & \multirow[b]{3}{*}{ df } & \multirow{3}{*}{$\begin{array}{l}\text { Sig. } \\
(2- \\
\text { tailed })\end{array}$} \\
\hline & \multirow[b]{2}{*}{ Mean } & \multirow[b]{2}{*}{ SD } & \multirow{2}{*}{$\begin{array}{l}\text { Std. } \\
\text { Error } \\
\text { Mean }\end{array}$} & \multicolumn{2}{|c|}{$\begin{array}{l}95 \text { percent } \\
\text { Confidence Interval } \\
\text { of the Difference }\end{array}$} & & & \\
\hline & & & & Lower & Upper & & & \\
\hline $\begin{array}{l}\text { Total Knowledge Score (out } \\
\text { of } 10 \mathrm{pts} \text { ) }\end{array}$ & 2.500 & 2.540 & .449 & 3.416 & 1.584 & -5.568 & 31 & $.000 *$ \\
\hline $\begin{array}{l}\text { 2. What watershed is your } \\
\text { school in? }(2 \mathrm{pt})\end{array}$ & 1.500 & 0.762 & 0.135 & 1.775 & 1.225 & -11.136 & 31 & $.000 *$ \\
\hline $\begin{array}{l}\text { Total "Intent to Act" Score } \\
\text { (Q's } 1 \text { - 6) Optimal Score = } 30 \\
\text { pts }\end{array}$ & 0.781 & 5.123 & .906 & 2.628 & 1.066 & -.863 & 31 & .395 \\
\hline $\begin{array}{l}\text { 3. Volunteer to help the } \\
\text { watershed. }\end{array}$ & 0.594 & 1.341 & .237 & 1.077 & .110 & -2.505 & 31 & $.018^{*}$ \\
\hline $\begin{array}{l}\text { Total "Environmental } \\
\text { Attitudes" Score (Q's } 7 \text { - 13) } \\
\text { Optimal Score = 35 pts }\end{array}$ & -0.469 & 4.407 & .779 & 1.120 & 2.058 & .602 & 31 & .552 \\
\hline $\begin{array}{l}\text { Total Attitude Towards the } \\
\text { Environment Score (Optimal } \\
\text { Score }=65 \text { pts) }\end{array}$ & 0.25 & 7.532 & 1.332 & 3.028 & 2.403 & -.235 & 31 & .816 \\
\hline
\end{tabular}


An additional paired t-test of individual questions one through five showed that question two alone ("What watershed is your school in?") showed a significant increase of 1.5 points, $t(31)=-11.14, p<0.001$ (Table 4). Regardless of significance, however, all questions showed positive gains in mean scores. This result supports our first hypothesis that environmental knowledge would increase after participation in the RS program.

The results of the within-subjects analysis were that the Time main effect was significant, $\Lambda=0.454, F(1,26)=31.29, p<0.01$; as well as the Time $\mathrm{x}$ Ethnicity interaction, $\Lambda=0.79, F(2,26)=3.40, p=0.05$; and Time $\mathrm{x}$ Gender $\mathrm{x}$ Ethnicity $\Lambda=$ $0.76, F(2,26)=4.07, p=0.03$. The Time $\mathrm{x}$ Gender interaction was not significant, $\Lambda=$ $0.99, F(2,26), p=0.635$. The observed power of these findings are a large effect size for the Time main effect, $d=1.00$; and medium effect sizes for Time x Ethnicity, $d=0.59$ and Time x Gender x Ethnicity, $d=0.67$. Figure 5 shows pre- and posttest means for both gender and ethnic groups, and Figure 6 shows scores for ethnic groups broken down further by gender. These results suggest that ethnic groups differed in their response to the RS program, as measured by their knowledge gain. As Table 5 shows, Hispanic/Native American students did not benefit as much from the intervention as both

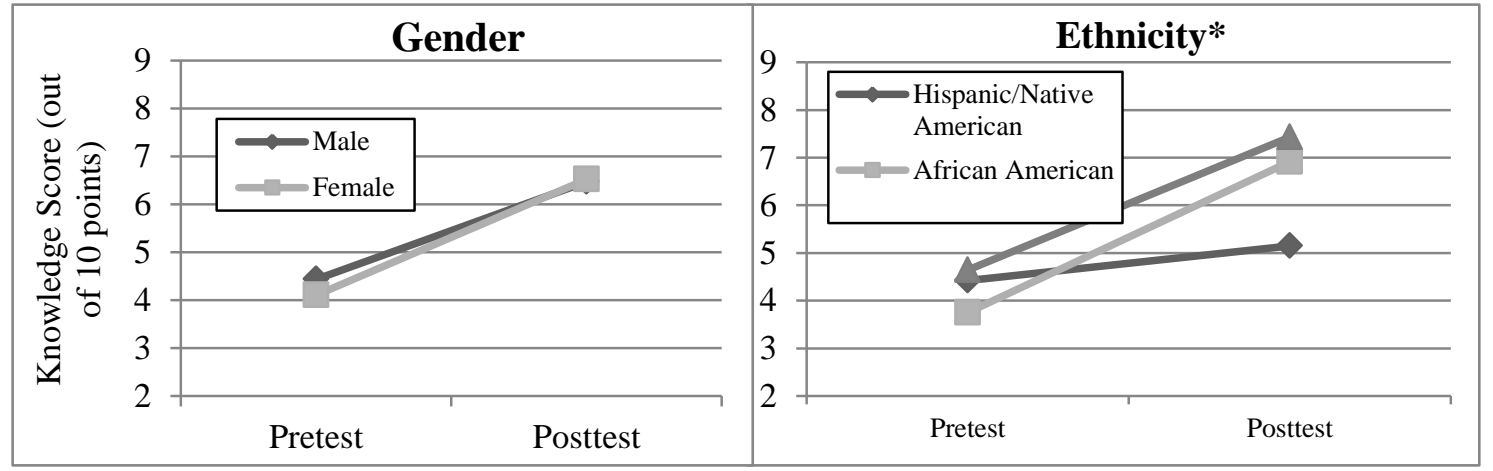

Figure 5. Pre- and Posttest Scores for Knowledge by Gender and Ethnicity * = significant within-groups 
African-American and White/Asian-American students (see also Figure 5). Overall, white students' knowledge scores increased by 2.79 (27.9 percent), African-American students' scores increased by 3.78 (37.8 percent), and Hispanic students' score increased by only 0.78 points ( 7.8 percent). Additionally, when ethnic groups are further broken down into gender categories, results indicate that Hispanic/Native-American, male students had the least gain of any gender/ethnic group combination with a gain of only 0.25 points ( 2.5 percent) versus 1.2 points ( 12 percent) for females. African-American females had the largest gain of 5 points (50 percent) compared with 1.3 point (13 percent) for African-American males. White/Asian males scored 3.58 points (35.8 percent) higher, while white/Asian females scored 2 points (20 percent) higher. These results suggest that ethnicity and gender together affected students' knowledge scores and support our third hypothesis that differences would be found within groups (Figure 5).

The results of the univariate tests to evaluate between-group differences were that the ANOVA was not significant for gender $\mathrm{F}(1)=0.05, \mathrm{p}=0.83$, ethnicity, $\mathrm{F}(2)=1.50$, $p=0.24$, or gender $x$ ethnicity, $F(2)=1.10, p=0.345$. These results suggest that despite differences in how the program affected individual students of different genders and ethnic groups, no between-subjects effect was found for either gender or ethnic groups. In other words, there was no significant difference between how different gender and ethnic groups responded to the program as a whole.. Thus, our fifth hypothesis was not supported, and no significant differences existed between groups. Overall trends were interesting, however, and will be examined further in the discussion section. 


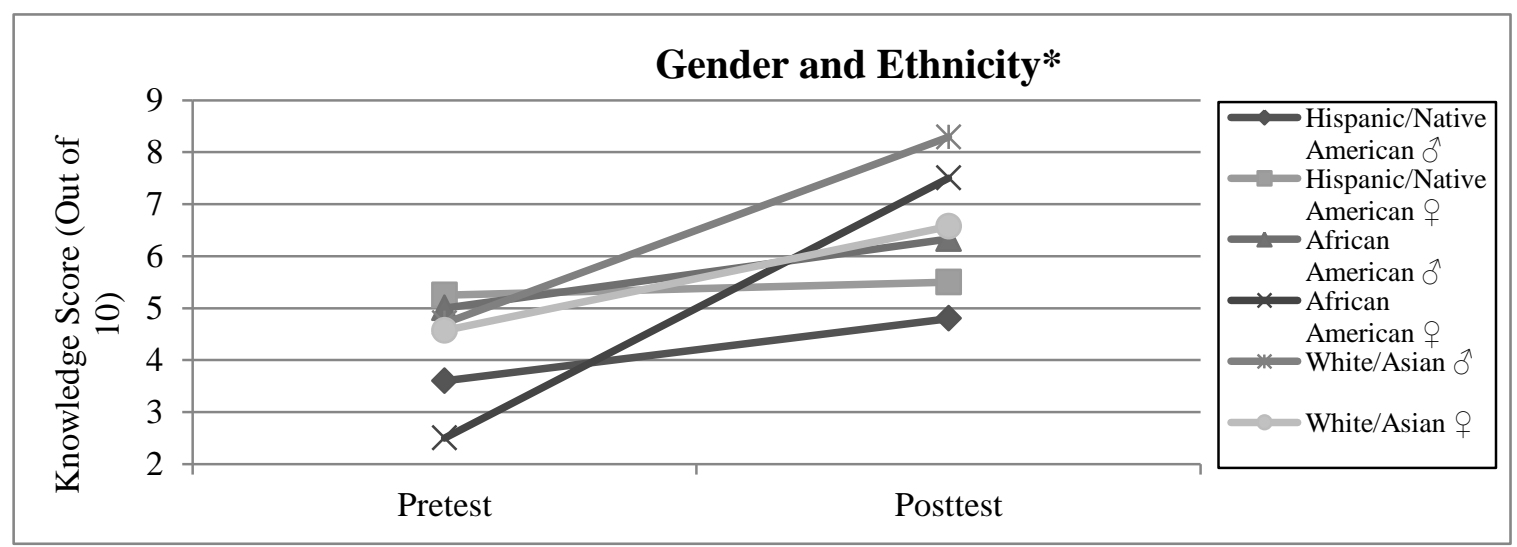

Figure 6. Pre-and Posttest Knowledge Scores for Ethnicity $x$ Gender * = significant within-group difference

Table 4. Descriptive Statistics for Knowledge Scores

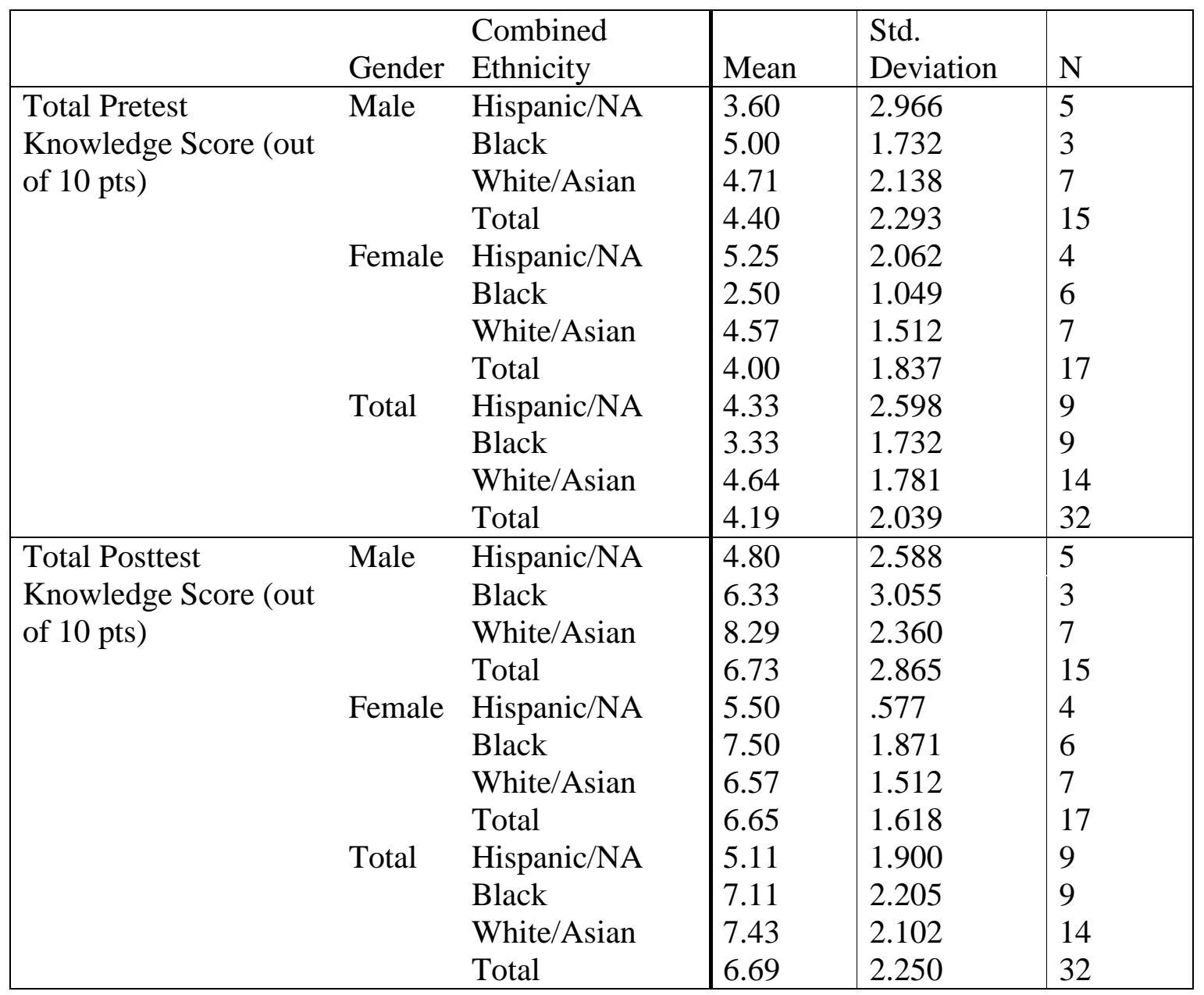




\section{Attitude}

Overall, students' ATE score increased less than one percent, or 0.25 points, which a paired t-test confirmed to be not significant $t(31)=-0.235, p=0.816$ (Table 4 , Table 6, Figure 2). Within the overall ATE, students' ITA increased by 4.14 percent, or 0.78 points, which a paired t-test revealed to be not significant, $t(31)=-0.86, p=0.40$, and EA decreased by 2.57 percent, which is also not significant, $t(31)=0.60, p=0.55$. When individual items were examined through the use of paired t-tests, only question three from the ITA section showed a significant increase of 22.8 percent or 0.594 points, $t(31)=-2.51, p=0.02$ (Figure 7). The nature of this question is telling, as it asked whether students would volunteer to help the watershed, and this finding will be considered further in the discussion section. Despite interesting trends in the data, however, we were unable to support our second hypothesis that students' attitudes would increase as a result of participation in the RS program.

Results of the within-subjects ANOVA for ATE showed that the main effect of attitude was not significant, $\Lambda=0.98, F(1,26)=0.47, p=0.50$, neither were Time $\mathrm{x}$ Gender, $\Lambda=0.95, F(1,26)=1.27, p=0.27$, Time $\mathrm{x}$ Ethnicity, $\Lambda=0.85, F(2,26)=2.25$, $p=0.13$, or Time $\mathrm{x}$ Gender $\mathrm{x}$ Ethnicity, $\Lambda=0.99, F(2,26)=0.12, p=0.89$. Figure 8 shows ATE graphed by gender and ethnicity. These results suggest that students' gender and ethnicity did not affect changes in overall ATE, and thus, our fifth hypothesis that genders and ethnic groups would respond differently to the RS program was not supported. Time was not significant, $\Lambda=0.99, F(1,26)=0.19, p=0.67$, and neither were Time $\mathrm{x}$ Gender, $\Lambda=0.99, F(1,26)=0.33, p=0.57$, Time $\mathrm{x}$ Ethnicity, $\Lambda=$ 
$0.85, F(2,26)=2.32, p=0.12$, or Time $\mathrm{x}$ Gender $\mathrm{x}$ Ethnicity, $\Lambda=0.99, F(2,26)=0.08$, $p=0.92$. These results suggest that the RS program did not affect students of different genders and ethnicities differently in terms of changing their ATE, ITA, or EA. Graphs of ITA and EA are shown in Figures 9 and 10, respectively.

The results of the univariate tests to evaluate between-group differences for ATE were that the ANOVA was not significant for gender, $F(1)=1.55, p=0.23$, ethnicity, $F(2)=0.58, p=0.57$, or gender $\mathrm{x}$ ethnicity, $F(2)=0.36, p=0.70$. Subvariable ITA likewise had no significance between groups for gender, $F(1)=0.60, p=0.45$, ethnicity, $F(2)=0.23, p=0.79$, or gender $\mathrm{x}$ ethnicity, $F(2)=0.33, p=0.72$. Subvariable EA also showed no significant difference between groups for gender, $F(1)=2.28, p=0.14$, ethnicity, $F(2)=0.88, p=0.43$, or gender $\mathrm{x}$ ethnicity, $F(2)=1.08, p=0.36$. These results suggest that there were no differences between groups in terms of their ATE, EA, or ITA and thus our sixth hypothesis that we would see differences between groups

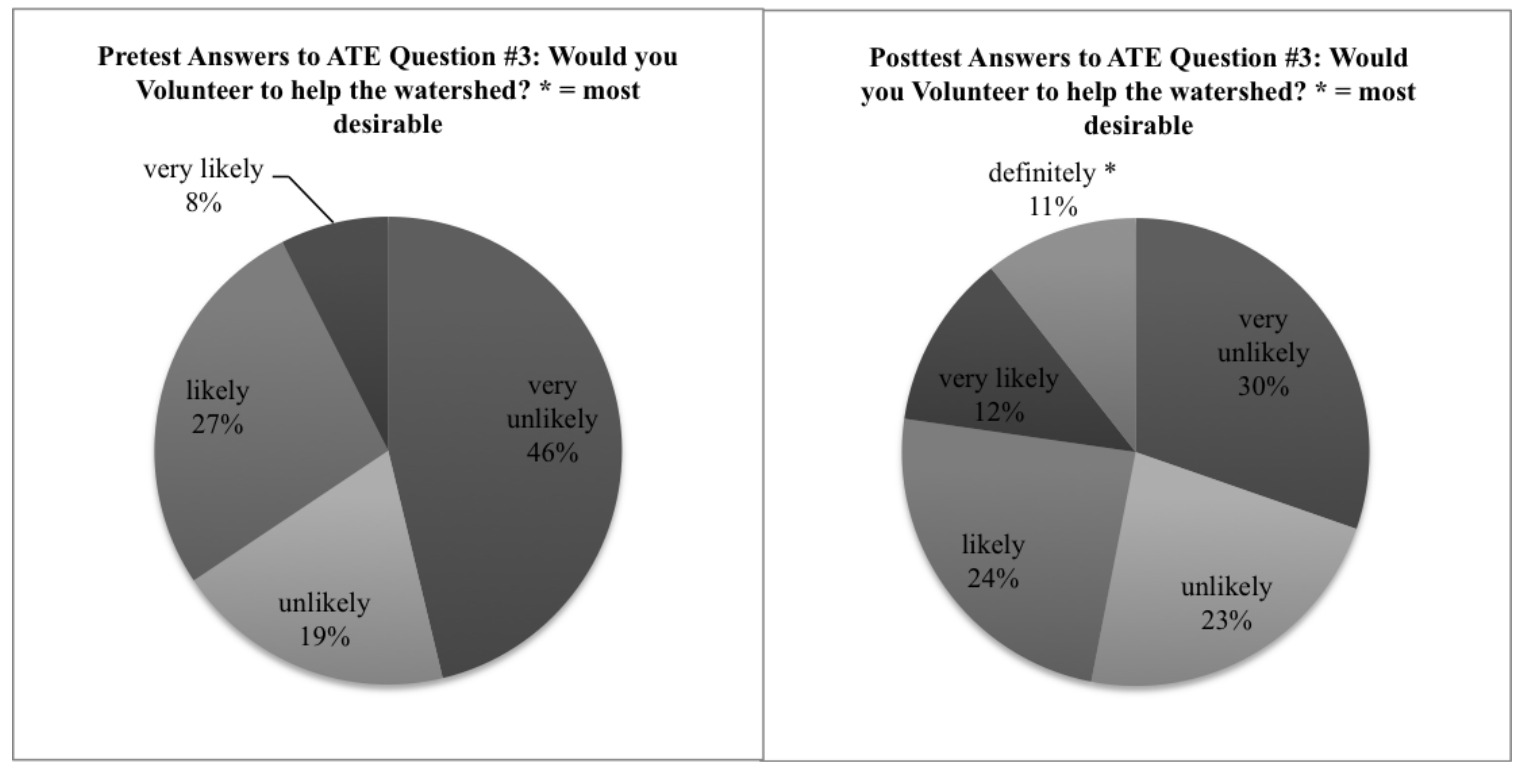

Figure 7.Percentages of Students' Responses to Question Three on the ATE Portion of Our Survey 
regarding their ATE was not supported.

The overwhelming conclusionof these results suggest that there was no change in attitude in GCWS sixth graders after the RS intervention. However, it should be noted that the power of these tests was very low due to the small sample size of our study. Indeed, initial analysis of the aggregate data $(\mathrm{N}=67)$ showed significant differences in attitudes between and within groups in terms of their attitudes. Thus, we will discuss the overall observed change in attitudes in the discussion section of this paper in terms of promising future research.

Table 5. Descriptive Statistics for ATE

\begin{tabular}{|c|c|c|c|c|c|}
\hline & Gender & $\begin{array}{l}\text { Combined } \\
\text { Ethnicity }\end{array}$ & Mean & $\begin{array}{c}\text { Std. } \\
\text { Deviation }\end{array}$ & $\mathrm{N}$ \\
\hline \multirow{12}{*}{$\begin{array}{l}\text { Pretest ATE Score } \\
\text { (Maximum Score = } \\
60 \text { pts) }\end{array}$} & \multirow[t]{4}{*}{ Male } & Hispanic/NA & 37.00 & 9.301 & 5 \\
\hline & & black & 35.00 & 3.464 & 3 \\
\hline & & White/Asian & 37.00 & 6.455 & 7 \\
\hline & & Total & 36.60 & 6.706 & 15 \\
\hline & \multirow[t]{4}{*}{ Female } & Hispanic/NA & 38.75 & 2.872 & 4 \\
\hline & & black & 39.33 & 6.976 & 6 \\
\hline & & White/Asian & 42.43 & 5.623 & 7 \\
\hline & & Total & 40.47 & 5.614 & 17 \\
\hline & \multirow[t]{4}{*}{ Total } & Hispanic/NA & 37.78 & 6.870 & 9 \\
\hline & & black & 37.89 & 6.173 & 9 \\
\hline & & White/Asian & 39.71 & 6.462 & 14 \\
\hline & & Total & 38.66 & 6.358 & 32 \\
\hline \multirow{12}{*}{$\begin{array}{l}\text { Posttest ATE Score } \\
\text { (Maximum Score = } \\
60 \text { pts) }\end{array}$} & \multirow[t]{4}{*}{ Male } & Hispanic/NA & 42.20 & 4.764 & 5 \\
\hline & & black & 37.33 & 6.807 & 3 \\
\hline & & White/Asian & 36.14 & 4.634 & 7 \\
\hline & & Total & 38.40 & 5.501 & 15 \\
\hline & \multirow[t]{4}{*}{ Female } & Hispanic/NA & 42.00 & 5.831 & 4 \\
\hline & & black & 37.17 & 5.913 & 6 \\
\hline & & White/Asian & 39.71 & 7.952 & 7 \\
\hline & & Total & 39.35 & 6.680 & 17 \\
\hline & \multirow[t]{4}{*}{ Total } & Hispanic/NA & 42.11 & 4.910 & 9 \\
\hline & & black & 37.22 & 5.783 & 9 \\
\hline & & White/Asian & 37.93 & 6.522 & 14 \\
\hline & & Total & 38.91 & 6.077 & 32 \\
\hline
\end{tabular}




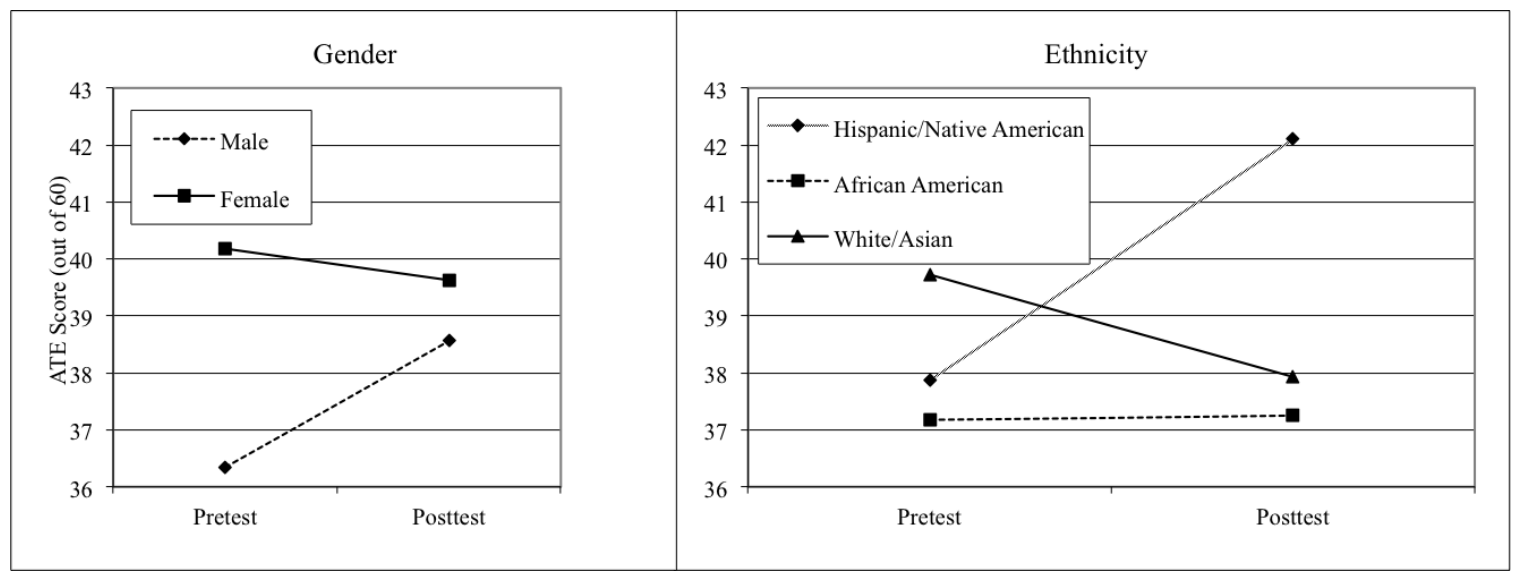

Figure 8. Pre- and Posttest Scores for ATE by Gendery and Ethnicity

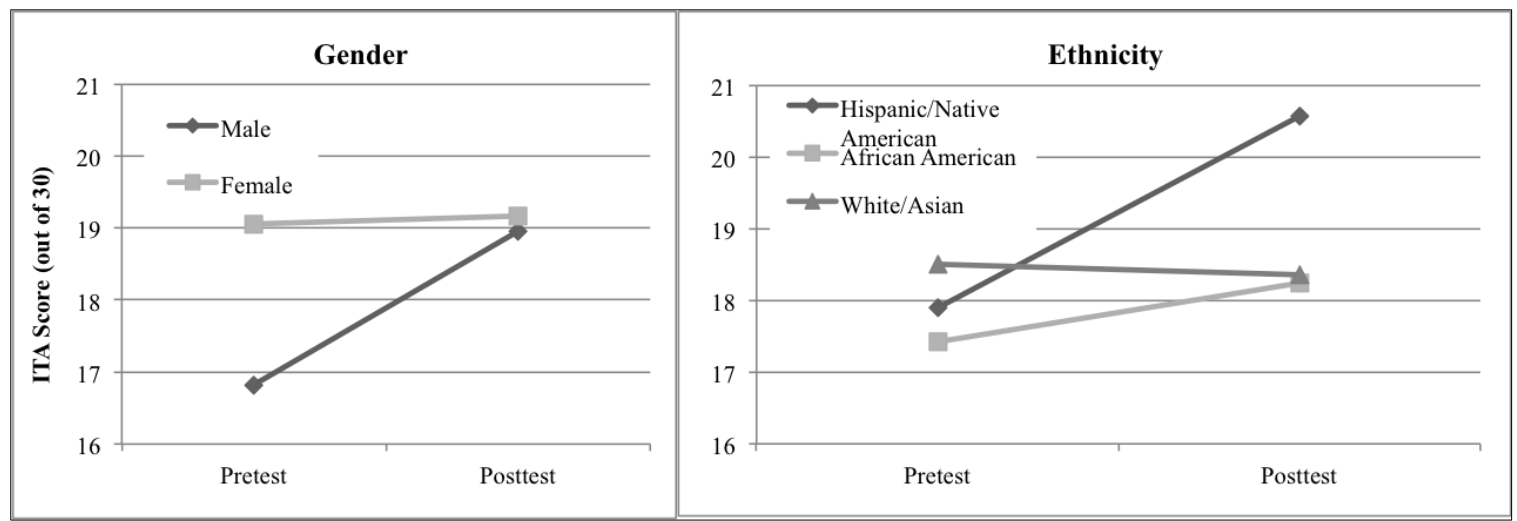

Figure 9. Pre- and Posttest Scores for ITA by Gender and Ethnicity

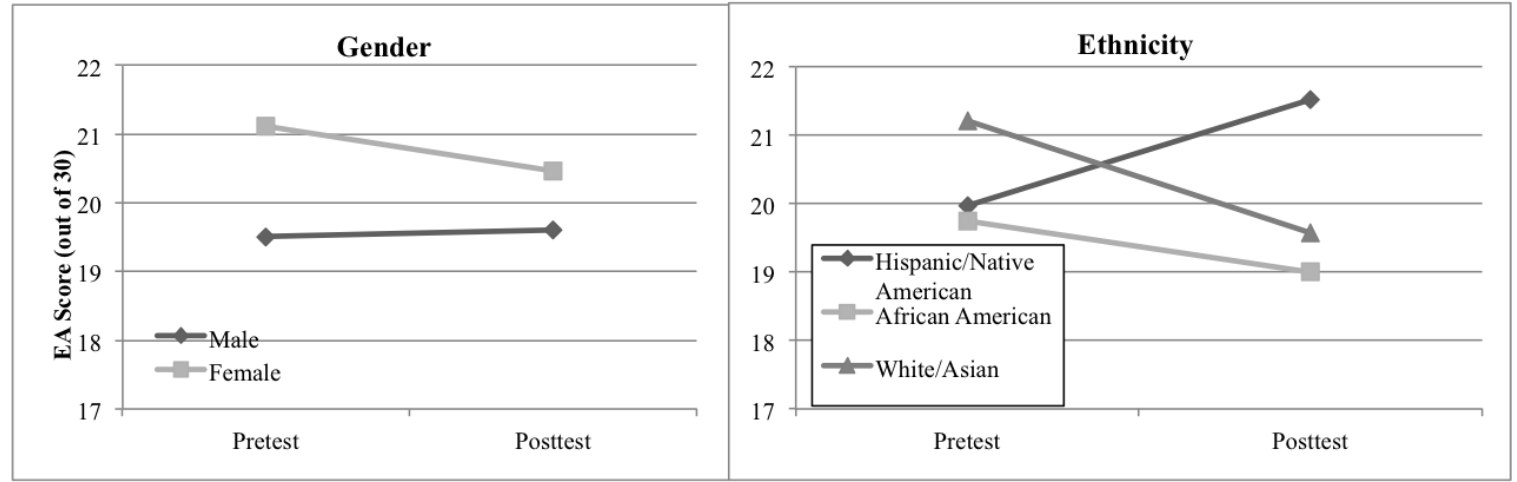

Figure 10. Pre- and Posttest Scores for EA by Gender and Ethnicity 


\section{Discussion}

Overall, the results of our quantitative analysis suggest that students' did benefit from exposure to the RS program through a gain in environmental knowledge, but did not exhibit a change in their ATE. I will now discuss these findings further individually and together, and, additionally, examine interesting trends that we observed in our data. I would like to stress, however, that many of the tentative findings I discuss below were not found to be statistically significant, and thus should not be taken as statistical support of our hypotheses.

\section{Knowledge}

Our study found that, overall, students had a statistically significant, 25 percent increase in environmental knowledge after their exposure to the RS program. The large effect size of this finding is also encouraging in such a small sample, indicating that the program had a large benefit to students in regards to knowledge gains. A gain in environmental knowledge is typical after exposure to an EE program (Beatty, 2007; Fisman, 2005; Leeming, 1997; Meinhold \& Malkus, 2005; Zint, Kraemer, Northway, \& Lim, 2002). Our study also suggested that males and females as whole groups did not show a significant difference in their response to the program or between groups which is consistent with a study by Carrier (2007), that found no differences in environmental knowledge between gender groups.

Our study did, however, find a significant difference in how ethnic groups were affected by the RS program. Both White/Asian and African-American ethnic groups benefited similarly from the program, Hispanic/Native American students, while starting 
out near Whites/Asians in terms of environmental knowledge, lagged behind in terms of gain and ended below both White/Asian and African-American students after the conclusion of the program (Figure 4). When ethnic groups were further divided into genders, it was revealed that Hispanic/Native American males faired the worst, overall, lagging behind and ending the lowest in their posttest environmental knowledge score (Figure 5). This finding is consistent with a study by Heard and Cantu-Mireles (1995) that examined ethnic groups' response to a thematic science course. Heard and CantuMireles also saw that Anglo and Black students benefited more than Hispanics in terms of knowledge gain.

There could be many different reasons for the gap between Hispanic/Native American students and their peers, but one may be a language barrier, as many of the students that make up the Hispanic demographic at GWCS are also considered English as a Second Language Learners (ESL). A couple of focus group responses seem to support this idea. When asked in a focus group what he did not like about science during the 2006-2007 school year, Eduardo, a Hispanic male student, replied:

I do not like tests and quizzes, but in science when Ms. XXXX was doing powerpoints, she was going too fast and sometimes I missed really important information and that is why my tests and quizzes got bad grades.

In another focus group, Nicolas, another Hispanic male student, responded to the same question of least favorite activities by agreeing with another student who claimed to hate the writing we did, "me, too, the writing. I wouldn't know what words to start with or what words to end with.” These two responses could suggest that these students were struggling with both comprehension and use of English. 
Another interesting finding is the response of African-American females to the RS program. While they started at the bottom of all groups on the pretest, they shot up an amazing five points (50 percent) to finish second only to White/Asian males on their posttest scores. This finding suggests that the RS program benefited this demographic greatly. This finding is consistent with studies that have suggested that females prefer science that is personally relevant and has connections to their lives (Rosser 1990, as cited in Shroyer, Backe, \& Powell, 1995). Shroyer, Backe, \& Powell's (1995) research also suggested that both male and female students prefer activities that are outside of the "middle school teaching" environment and include more active participation, as the majority of the RS program activities do. Alicia, an African-American female student, seems to echo this idea:

Hands-on learning is one of my favorite things to learn science with in all my subjects because you don't just get to heard about and read about it. You get to see it and touch it and feel its texture, if it is smooth or rough, instead of just hearing about it.

\section{Attitude Toward the Environment}

Overall, the ATE of students' at GWCS was considered to be positive, with scores of all participants, regardless of gender and ethnicity above a neutral 30 points. While we were unable to find any significant differences in overall attitude scores or within or between groups, when we graphed the data, we saw several trends that we feel bear further investigation in a larger study/future research.

First, as shown in Figure 7, males lagged behind females in overall ATE both before and after the RS program. Despite this, males benefited more from the program in 
terms of gains in ATE and EK than females, who actually marginally declined between the pre- and posttest. This is consistent with Carrier (2007) who found males to benefit more from an EE program although the researcher found no statistical difference between the genders overall. One explanation could be that girls started with a higher attitude and therefore had little more to gain. This type of ceiling effect was also noted in a study by Eagles and Demare (1999), who suggested that students who come into an environmental program with moderate levels of EA have little room to improve. A quote from Ida, one of the sixth-grade teachers involved in this study, seemed to correlate the trend of higher female ATE:

Actually, I thought I saw more girls who were interested. When we planted the bulbs in the garden, it was more of the girls getting on their hands and knees and not enough trowels to go around, I had Jaime use her hands. She said, 'oh, I do this all the time.' I think yeah, it was a lot of girls. My boys were reluctant to get dirty. This is just what I saw and seem to think. The boys had good answers, they were there trooping around the pond, but it just seems that it was my girls who seemed to get into it. Even with the macroinvertebrates, that was a good one. Hands-on. Boys and girls both of them for that one.

When ethnic groups were examined, there were additional interesting trends to observe. African-American students had the lowest ATE of all groups, and their scores did not improve at all after the RS program. Hispanic/Native American students, on the other hand, increased their ATE score by several points, while White/Asian students actually decreased. These findings may suggest that the RS program impacts various ethnic groups differently, which would be consistent with general science findings which document an "achievement gap" between ethnic groups (Norman, Ault, Bentz, \& 
Meskimen, 2001; Rodriguez, 1998). We feel that this trend merits additional investigation. A possible reason for this gap in attitudes was suggested by Ida:

In my mind I am thinking that for the African community, the emphasis is on survival, or paycheck to paycheck, hand-to-mouth. Not all of them are that way, but in our community here, many of them, that is their main emphasis on a day-to-day basis. They don't have the luxury of time to think outside and about environmental issues. Because it doesn't pertain to them. What pertains to them is feeding the family, getting the rent paid. It almost ends up being survival. Environmental issues are no part of their lives.

While Ida's quote confounds the issues of race and socio-economic status, it is often true that in many metropolitan areas of United States, poverty and minority status are linked. Furthermore, the idea of Socio-economic status affecting how students react to the environment is not new. It has been suggested in other studies that issues pertaining to safety and economic survival may impact how children perceive and explore their local environment (Fisman, 2005).

Future research relating ethnicity and socio-economic status of participants may begin to shed light on this issue, although it is important to remember that African-American students in our study still had an ATE score of above 30, and thus trending towards the positive.

When the subvariables of ITA and EA are examined (Figures 9 and 10), we see that similarly to the overall ATE scores, males score lower on each of the subvariables than females, but males increased their ITA, while their EA shows practically no change. This could suggest that through their participation in the RS program, males felt more inclined to personally take action that helps the environment, another interesting question to explore in future studies. 
When ethnicities are examined, similar trends are shown as for the general findings of ATE. In both ITA and EA, Hispanic/Native Americans show a sharp increase. White/Asian students, however, show little change in their ITA and a decrease in their EA. African-American students, on the other hand show a modest increase in ITA and a similar decease to White/Asian students in their EA. Why Hispanic students increased in their ITA and EA while White/Asian and African-American students decreased or remained static is unknown, but could provide fertile ground for future research.

\section{Knowledge and Attitudes Toward the Environment Taken Together}

Looking at the interplay of knowledge and attitudes, the item of most interest to the researchers is that ethnic groups who benefited the most in terms of knowledge gain, White/Asian and African-American, were those that also showed little to no change, or even a slight decrease in their ATE. Interview data may help tease out this at-odds finding. For instance, Sylvia, a sixth-grade science teacher was asked if she thought the RS program benefited all races and genders equally and suggested that students with the perceived lowest attitudes may benefit the most from EE, which fits with our quantitative findings:

Well I would break that question down a little further. I would say that it does benefit all groups equally, but I think that there are some groups that certainly have a greater comfort level and are probably getting a deeper level of new knowledge and understanding out of it. But, I think it is kind of a continuum. As far as where students stand as far as comfort and attitude and understanding and awareness towards the environment ... It was always the African-American kids who didn't like it or the African-American kids who didn't want to do it or go or who were grumpy. But I also know that when those kids would be out in the field, they usually really got into it. But they did start with a bigger level of apprehension. Everything was more unfamiliar, it was scarier, it was gross, it was getting their white shoes dirty or whatever that case may be, but once they acclimated, I still think they benefited from it. I would say that as far as 
general... some of this is a generalization, but it is based on observations, it seemed like Latino children and the white population seemed to be the most comfortable and at ease in the environment. I would say there was more of a variety amongst the white kids and the Latino kids seemed, across the board, to feel comfortable and interested. Again, getting back to the continuum idea, there was benefit to all the groups they just had very different starting points.

\section{An Emerging Sense of Place?}

In addition to our general observations, we find encouragement that students seemingly gained a better sense of their place within the watershed and a stronger connection to its health. To support this idea, we submit that the two questions in our survey that showed significant change when examined in a paired t-test, question two in the knowledge section and question three in the ATE portion, both are particularly relevant to students' sense of place within their watershed and their willingness to take personal action.

Question two in the EK section asks students "What watershed in your school in" and most students scored two out of two points after the intervention compared with no students scoring full points on the pretest. When students with partial credit (one point) are combined with this percentage, we see that 87.6 percent of students were able to get partial credit on this question (Figure 3).

Question three on the ATE portion asks students how likely they are to "volunteer to help the watershed" and may suggest that students' felt more empowered to take the health of the watershed into their own hands. Prior to the intervention, no students gave the most desirable response of "definitely," compared to $11 \%$ afterwards. When negative responses (very unlikely and likely) and positive responses (likely, very likely, and 
definitely) are grouped this shift is more evident. Prior to the intervention, only $35 \%$ of students gave a positive response compared to $47 \%$ after the intervention (Figure 7).

Meinhold and Malkus (2005) found a connection between self-efficacy, defined as "the confidence that individuals have in their ability to plan and execute a course of action and to accomplish a task or solve a problem," and females' environmental attitudes and ERB. Thus our finding is encouraging in that it may suggest that participation in the RS program increases students' feeling that they can make a difference. However, instead of an increase in self-efficacy, it may also be simply that students became more aware of their local environment, as suggested by this quote from Ramona, a white, female student:

I used to live in the country so everything was like really good and then I went to Southeast Rivertown and then now I live in North Rivertown and I just think that the city sucks. No trees or pretty rivers, nothing to do. No canoeing actually. Going to River School changed that. I didn't know that there were some pretty little ponds with eagles that killed fish or that we could go canoeing. That was really awesome. I think it kinda changed my whole perspective on the cities and North Rivertown especially.

\section{Future Research}

It is the hope of the researcher that this study will provide a starting point for further inquiry into gender and ethnicity studies within the realm of EE. Several paths of additional research are suggested by our results, and include:

1) More general research into the differences between how ethnic groups respond to EE programs in order to build up a body of knowledge on this topic 
2) Research on how the interplay of ethnicity and socio-economic status affect ATE, EK, and responses to EE programs

3) Research on differences in ATE between ethnic groups

4) Additional research into gender differences in ATE and its subvariables EA and ITA

In addition, we would like to mention another interesting topic of potential research that surface in reviewing our qualitative data, but which was not involved in this study. During our discussions with teachers, the RS educator, and our own observations, we noticed that peer-pressure seemed to play an important role in how students' engaged with the RS program. For example, students regularly asked each other in class when field trips were announced, "are you going?" Additionally, we noticed that on field trips, if the perceived "popular" students were engaged and willing to participate in activities, the rest of the group followed along and, conversely, if the popular students were not engaged, the rest of the group largely followed suit. We feel like this observation lends itself to future research to examine how students' ATE and environmental knowledge are affected by peer-pressure and the perception of EE activities being "cool."

\section{Conclusion}

This study sought to document changes in environmental knowledge (EK) and Attitude Toward the Environment (ATE) after a one-year environmentally-focused curriculum was implemented in an urban sixth-grade classroom in the Pacific Northwest. In addition, we wished to examine any changes in EK and ATE through the lenses of 
gender and ethnicity to illuminate how these programs potentially affect groups differently.

The environmental movement of the past few decades and increased awareness of environmental issues has led to the formation of numerous educational organizations in United States with the purpose of positively impacting the environmental attitudes (EA) and environmental knowledge (EK) of participants. Impacting these two variables has been linked to the promotion of Environmentally-Responsible Behavior and a goal of decreasing human impact on the environment (Meinhold \& Malkus, 2005). However, despite the presence of numerous environmental-education programs, there is very little research on how EE programs affect different participant groups. Studies focusing on gender differences have been inconclusive (Carrier, 2007; Tikka, Kuitunen, \& Tynys, 2000; Zelezny, Chua, \& Aldrich, 2000), and studies focusing on differences between ethnic groups are scarce.

As United States becomes more diverse, it is crucial that these factors are considered when evaluating the effectiveness of EE programs to ensure the forward momentum of the environmental movement. It is our hope that our findings will aid the River School's efforts to improve its practices and address the needs of a diverse constituency.

In addition to the goal of improving Environmental Education is the equally important goal of continuing to offer EE as a viable supplement to existing school curricula. As the educational reform movement continues to focus on high-stakes testing as a measure of student success alterative curriculum is increasingly questioned. As 
pressure builds to eliminate "excess" programming and focus more on what is on "the test," it is crucial that EE programs can document their benefits to students from all backgrounds. Furthermore, we wish for programs like RS to continue to thrive as teachers see the benefits of the program in terms of increasing engagement in science and connections to their local communities.

The results from this investigation were mixed. We were unable to support many of our hypotheses focused on expected differences between gender and ethnic groups. However, even with a small sample size, there were several interesting findings

. Our quantitative results suggest that while there was a significant increase in EK overall, there were no significant differences in EK between males and females, consistent with other studies (Carrier, 2007). However, when ethnicity is added, there were significant differences between both ethnic groups and gender $\mathrm{x}$ ethnic groups. In particular, Hispanic/Native American Male students lagged behind their peers, a finding that could be indicative of language barriers. We feel encouraged that, despite our small sample size, we were able to find differences between groups and we feel our results provide a basis for future research with larger groups of participants.

In terms of ATE, we found no significant differences between gender, ethnic, and gender $\mathrm{x}$ ethnic groups in terms of ATE and its subvariables EA and ITA. This is not consistent with other studies which have taken place in general science settings (Norman, Ault, Bentz, \& Meskimen, 2001; Rodriguez, 1998) which have noted differences between ethnic groups in their attitudes towards science. There is a lack, however, of these types of studies in EE, and we still observed trends that we feel need additional exploration. 
One topic of interest is the difference between ATE starting points of different ethnic groups and why some groups improved in their ATE and some declined. For example, African-American students had the lowest ATE of all the groups and this value did not improve. It is also worth noting here that when we examined the whole group data $(n=67)$, not just those students who returned consent forms $(n=32)$, we did see significant differences between genders $\mathrm{x}$ ethnic groups in ATE. While we cannot comment on those differences, we feel that there is plenty of fertile ground for future research.

In conclusion, our research represents an initial investigation into important questions around disparities in $\mathrm{EE}$ and will hopefully inspire others to continue to explore this topic. It is our belief that continued research into these complex interactions is critical as United States continues to become more ethnically diverse and the state of the environment continues to decline in the wake of the monumental challenges of population growth and climate change. 


\section{References}

Aiken, L. R. (1996). Rating Scales and Checklists. New York, NY: John Wiley \& Sons, Inc.

Airasian, P. W., Cruikshank, K. A., Mayer, R. E., Pintrich, P. R., Raths, J., \& Wittrock, M. C. (2001). A Taxonomy for Learning, Teaching, and Assessing: A revision of Bloom's Taxonomy of Educational Objectives (2nd ed.). New York, NY: Longman.

Ajzen, I., \& Fishbein, M. (1980). Understanding attitudes and predicting social behavior. Englewood Cliffs, N.J.: Prentice-Hall.

Arcury, T. A. (1990). Environmental attitude and environmental knowledge. Human Organization, 49(4), 300-304.

Arcury, T. A., \& Johnson, T. P. (1987). Public Environmental Knowledge: A Statewide Survey. Journal of Environmental Education, 18(4), 31-37.

Bamberg, S., \& Moser, G. (2007). Twenty years after Hines, Hungerford, and Tomera: A new meta-analysis of psycho-social determinants of pro-environmental behavior. Journal of Environmental Psychology, 27(1), 14-25.

Beatty, G. (2007). Assessment Report (pp. 26): Clean River Education Program, Bureau of Environmental Services In partnership with the Center for Science Education, Portland State University

Bradley, J. C., Waliczek, T. M., \& Zajicek, J. M. (1999). Relationship between environmental knowledge and environmental attitude of high school students. The Journal of Environmental Education, 30(3), 17-21.

Bryant, C. K., \& Hungerford, H. R. (1977). An analysis of strategies for teaching environmental concepts and values clarification in kindergarten. The Journal of Environmental Education, 9(1), 44-49.

Carrier, S. J. (2007). Gender differences in attitudes towards environmental science. School Science and Mathematics, 107(7), 271-278.

Coe, R. (2002, 12-14 September). It's the Effect Size, Stupid: What effect size is and why it is important. Paper presented at the British Educational Research Association Annual Conference, Exeter, UK.

Cole, A. G. (2007). Expanding the Field: Revisiting Environmental Education Principles Through Multidisciplinary Frameworks. The Journal of Environmental Education, 38(2), 35-44.

Disinger, J. F. (2001). K-12 Education and the Environment: Perspectives, Expectations, and Practice. The Journal of Environmental Education, 33(1), 4-11.

Dunlap, R. E., \& Van Liere, K. D. (1978). The "New Environmental Paradigm": A Proposed Measuring Instrument and Preliminary Results. Journal of Environmental Education, 9, 10-19.

Eagles, P. F. J., \& Demare, R. (1999). Factors influencing children's environmental attitudes. Journal of Environmental Education, 30(4), 33-37.

Fisman, L. (2005). The effects of local learning on environmental awareness in children: An empirical investigation. The Journal of Environmental Education, 36(3), 3950. 
Fraenkel, J. R., \& Wallen, N. E. (2006). How to Design and Evaluate Research in Education (6th ed.). New York, NY: McGraw Hill Higher Education.

Garson, G. D. (2008, 3/9/08). Scales and Standard Measures. Retrieved March 21, 2008, from http://www2.chass.ncsu.edu/garson/pa765/standard.htm

Gruenewald, D. A. (2003). The Best of Both Worlds: A Critical Pedagogy of Place. Educational Researcher, 32(4), 3-12.

Gruenewald, D. A., \& Manteaw, B. O. (2007). Oil and water still: how No Child Left Behind limits and distorts environmental education in US schools. Environmental Education Research, 13(2), 171-188.

Heard, V. G., \& Cantu-Mireles, C. (1995). Gender and ethnicity factors in student achievement in a coordinated thematic science course. In D. R. Baker \& K. Scantlebury (Eds.), Science "Coeducation": Viewpoints from Gender, Race and Ethnic Perspectives. NARST Monograph. (Vol. 7). Columbus, OH: National Association for Research in Science Teaching.

Hines, J. M., Hungerford, H. R., \& Tomera, A. N. (1987). Analysis and synthesis of research on responsible environmental behavior: A meta-analysis. Journal of Environmental Education, 18(2), 1-8.

Kellert, S. R. (1979). Public Attitudes Toward Critical Wildlife and Natural Habitat Issues, Phase I Washington, D.C.: Government Printing Office.

Kraemer, A., Zint, M., \& Northway, H. (1999). Chesapeake Bay Foundation Education Program Evaluation (Executive Summary). Annapolis, MD: Chesapeake Bay Foundation.

La Trobe, H. L., \& Acott, T. G. (2000). A modified NEP/DSP environmental attitudes scale. The Journal of Environmental Education, 32(1), 12-20.

Leeming, F. C. (1997). Effects of participation in class activities on children's environmental knowledge and attitudes. The Journal of Environmental Education, 28(2), 33-42.

Leeming, F. C., Dwyer, W. O., \& Bracken, B. A. (1995). Children's Environmental Attitude and Knowledge Scale: Construction and Validation. Journal of Environmental Education, 26(3), 22.

Lieberman, G. A., \& Hoody, L. L. (1998). Closing the Achievement Gap: Using the Environment as an Integrating Context for Learning. Executive Summary. Washington, DC: Council of Chief State School Officers, Pew Charitable Trusts.

Marouli, C. (2002). Multicultural Environmental Education: Theory and Practice. Canadian Journal of Environmental Education, 7(1), 26.

Meinhold, J. L., \& Malkus, A. J. (2005). Adolescent environmental behaviors: Can knowledge, attitudes, and self-efficacy make a difference? Environment and Behavior, 37(4), 511-532.

Musser, L. M., \& Malkus, A. J. (1994). The Children's Attitudes toward the Environment Scale. Journal of Environmental Education, 25(3), 22.

Norman, O., Ault, C., Bentz, B., \& Meskimen, L. (2001). The black-white achievement gap as a perennial challenge of urban science education: A sociocultural and historical overview with implications for research and practice. Journal of Research in Science Teaching, 38(10), 1101-1114. 
Nunnally, J. C. (1978). Psychometric Theory (2nd ed.). San Francisco, CA: McGraw-Hill Book Company.

Rodriguez, A. J. (1998). Strategies for counterresistance: Toward sociotransformative constructivism and learning to teach science for diversity and for understanding. Journal of Research in Science Teaching, 35(6), 589-622.

Seacrest, S. S., \& Herpel, R. (1997). Developing a results-oriented approach for water education programs. Journal of the American Water Resources Association, 33(2), 261-270.

Shroyer, M. G., Backe, K., \& Powell, J. C. (1995). Developing a science curriculum that addresses the learning perspectives of male and female middle level students. In D. R. Baker \& K. Scantlebury (Eds.), Science "Coeducation": Viewpoints from Gender, Race and Ethnic Perspectives. NARST Monograph (Vol. 7). Columbus, $\mathrm{OH}$ : National Association for Research in Science Teaching.

Simon, S. (2004). What's a good value for Cronbach's Alpha? Retrieved March 15, 2008, from http://www.childrensmercy.org/stats/weblog2004/CronbachAlpha.asp

Smith, G. A. (2007). Placed-based education: breaking through the constraining regularities of public school. Environmental Education Research, 13(2), 189-207.

Stapp, W. B., Bennet, D., Bryan, W., Fulton, J., MacGregor, J., Nowak, P., et al. (1969). The concept of environmental education. The Journal of Environmental Education, 1(1), 30-31.

Taskin, O. (2003, January 29-February 2). The Ignored Facets of Environmental Attitute and Knowledge Scales. Paper presented at the Annual Meeting of the Association for the Education of Teachers of Science, St. Louis, MO.

Tikka, P. M., Kuitunen, M. T., \& Tynys, S. M. (2000). Effects of Educational Background on Students' Attitudes, Activity Levels, and Knowledge Concerning the Environment. Journal of Environmental Education, 31(3), 12.

Volk, T. L., \& Cheak, M. J. (2003). The Effects of an Environmental Education Program on Students, Parents, and Community. The Journal of Environmental Education, 34(4), 12-25.

Wiggins, G., \& McTighe, J. (2001). What is Backwards Design? In Understanding by Design (1st ed., pp. 7-19). Upper Saddle River, NJ: Merrill Prentice Hall.

Zelezny, L. C., Chua, P.-P., \& Aldrich, C. (2000). Elaborating on gender differences in environmentalism. Journal of Social Issues, 56(3), 443-457.

Zint, M., Kraemer, A., Northway, H., \& Lim, M. (2002). Evaluation of the Chesapeake Bay Foundation's Conservation Education Programs. Conservation Biology, 16(3), 641-649. 


\section{Appendix A: SPSS Outputs}

Knowledge Tests of Within-Subjects Contrasts

\begin{tabular}{|c|c|c|c|c|c|c|c|c|c|}
\hline Source & knowledge & $\begin{array}{l}\text { Type III } \\
\text { Sum of } \\
\text { Squares }\end{array}$ & df & $\begin{array}{l}\text { Mean } \\
\text { Square }\end{array}$ & $F$ & Sig. & $\begin{array}{l}\text { Partial } \\
\text { Eta } \\
\text { Squared }\end{array}$ & $\begin{array}{l}\text { Noncent. } \\
\text { Parameter }\end{array}$ & $\begin{array}{l}\text { Observed } \\
\text { Power(a) }\end{array}$ \\
\hline time & Linear & 72.165 & 1 & 72.165 & 31.289 & .000 & .546 & 31.289 & 1.000 \\
\hline $\begin{array}{l}\text { time }^{*} \\
\text { gender }\end{array}$ & Linear & .531 & 1 & .531 & .230 & .635 & .009 & .230 & .075 \\
\hline $\begin{array}{l}\text { time }{ }^{*} \\
\text { ethnicity }\end{array}$ & Linear & 15.680 & 2 & 7.840 & 3.399 & .049 & .207 & 6.798 & .588 \\
\hline $\begin{array}{l}\text { time * } \\
\text { gender * } \\
\text { ethnicity }\end{array}$ & Linear & 18.764 & 2 & 9.382 & 4.068 & .029 & .238 & 8.136 & .671 \\
\hline Error(time) & Linear & 59.965 & 26 & 2.306 & & & & & \\
\hline
\end{tabular}

(a) Computed using alpha $=.05$

\section{Knowledge Tests of Between-Subjects Effects}

\begin{tabular}{|c|c|c|c|c|c|c|c|c|}
\hline Source & $\begin{array}{l}\text { Type III } \\
\text { Sum of } \\
\text { Squares }\end{array}$ & df & $\begin{array}{l}\text { Mean } \\
\text { Square }\end{array}$ & $\mathrm{F}$ & Sig. & $\begin{array}{c}\text { Partial } \\
\text { Eta } \\
\text { Squared }\end{array}$ & $\begin{array}{l}\text { Noncent. } \\
\text { Parameter }\end{array}$ & $\begin{array}{l}\text { Observed } \\
\text { Power(a) }\end{array}$ \\
\hline Intercept & 1689.931 & 1 & 1689.931 & 289.568 & .000 & .918 & 289.568 & 1.000 \\
\hline gender & .286 & 1 & .286 & .049 & .827 & .002 & .049 & .055 \\
\hline ethnicity & 17.503 & 2 & 8.752 & 1.500 & .242 & .103 & 2.999 & .290 \\
\hline $\begin{array}{l}\text { gender * } \\
\text { ethnicity }\end{array}$ & 12.942 & 2 & 6.471 & 1.109 & .345 & .079 & 2.218 & .223 \\
\hline Error & 151.737 & 26 & 5.836 & & & & & \\
\hline
\end{tabular}

(a) Computed using alpha $=.05$

\section{ATE Tests of Within-Subjects Contrasts}

\begin{tabular}{|c|c|c|c|c|c|c|c|c|c|}
\hline Source & ATE & $\begin{array}{l}\text { Type III } \\
\text { Sum of } \\
\text { Squares }\end{array}$ & df & $\begin{array}{c}\text { Mean } \\
\text { Square }\end{array}$ & $\mathrm{F}$ & Sig. & $\begin{array}{c}\text { Partial } \\
\text { Eta } \\
\text { Squared } \\
\end{array}$ & $\begin{array}{l}\text { Noncent. } \\
\text { Parameter }\end{array}$ & $\begin{array}{l}\text { Observed } \\
\text { Power(a) }\end{array}$ \\
\hline TIME & Linear & 10.299 & 1 & 10.299 & .468 & .500 & .018 & .468 & .101 \\
\hline $\begin{array}{l}\text { TIME * } \\
\text { gender }\end{array}$ & Linear & 27.923 & 1 & 27.923 & 1.270 & .270 & .047 & 1.270 & .192 \\
\hline $\begin{array}{l}\text { TIME * } \\
\text { ethnicity }\end{array}$ & Linear & 98.855 & 2 & 49.428 & 2.248 & .126 & .147 & 4.496 & .416 \\
\hline $\begin{array}{l}\text { TIME * } \\
\text { gender * } \\
\text { ethnicity }\end{array}$ & Linear & 5.041 & 2 & 2.521 & .115 & .892 & .009 & .229 & .066 \\
\hline Error(TIME) & Linear & 571.668 & 26 & 21.987 & & & & & \\
\hline
\end{tabular}

(a) Computed using alpha $=.05$ 
ATE Tests of Between-Subjects Effects

\begin{tabular}{|l|r|r|r|r|r|r|r|r|}
\hline Source & \multicolumn{1}{|c|}{$\begin{array}{l}\text { Type III } \\
\text { Sum of } \\
\text { Squares }\end{array}$} & \multicolumn{1}{c|}{ df } & \multicolumn{1}{c|}{$\begin{array}{c}\text { Mean } \\
\text { Square }\end{array}$} & \multicolumn{1}{c|}{ F } & \multicolumn{1}{c|}{$\begin{array}{c}\text { Partial } \\
\text { Eta } \\
\text { Squared }\end{array}$} & $\begin{array}{c}\text { Noncent. } \\
\text { Parameter }\end{array}$ & $\begin{array}{c}\text { Observed } \\
\text { Power(a) }\end{array}$ \\
\hline Intercept & 87139.917 & 1 & 87139.917 & 1536.322 & .000 & .983 & 1536.322 & 1.000 \\
\hline gender & 87.634 & 1 & 87.634 & 1.545 & .225 & .056 & 1.545 & .224 \\
\hline ethnicity & 65.388 & 2 & 32.694 & .576 & .569 & .042 & 1.153 & .135 \\
\hline $\begin{array}{l}\text { gender } \\
\text { ethnicity }\end{array}$ & 40.509 & 2 & 20.255 & .357 & .703 & .027 & .714 & .101 \\
\hline Error & 1474.715 & 26 & 56.720 & & & & & \\
\hline
\end{tabular}

(a) Computed using alpha $=.05$

\section{ITA Tests of Within-Subjects Contrasts}

\begin{tabular}{|c|c|c|c|c|c|c|c|c|c|}
\hline Source & ITA & $\begin{array}{l}\text { Type III } \\
\text { Sum of } \\
\text { Squares }\end{array}$ & df & $\begin{array}{l}\text { Mean } \\
\text { Square }\end{array}$ & $\mathrm{F}$ & Sig. & $\begin{array}{c}\text { Partial } \\
\text { Eta } \\
\text { Squared }\end{array}$ & $\begin{array}{c}\text { Noncent. } \\
\text { Parameter }\end{array}$ & $\begin{array}{l}\text { Observed } \\
\text { Power(a) }\end{array}$ \\
\hline ITA & Linear & 18.332 & 1 & 18.332 & 1.311 & .263 & .048 & 1.311 & .197 \\
\hline ITA * gender & Linear & 14.997 & 1 & 14.997 & 1.072 & .310 & .040 & 1.072 & .169 \\
\hline $\begin{array}{l}\text { ITA * } \\
\text { ethnicity }\end{array}$ & Linear & 21.627 & 2 & 10.813 & .773 & .472 & .056 & 1.546 & .167 \\
\hline $\begin{array}{l}\text { ITA * gender } \\
\text { * ethnicity }\end{array}$ & Linear & 6.115 & 2 & 3.058 & .219 & .805 & .017 & .437 & .081 \\
\hline Error(ITA) & Linear & 363.594 & 26 & 13.984 & & & & & \\
\hline
\end{tabular}

(a) Computed using alpha $=.05$

\section{ITA Tests of Between-Subjects Effects}

\begin{tabular}{|l|r|r|r|r|r|r|r|r|}
\hline Source & $\begin{array}{c}\text { Type III } \\
\text { Sum of } \\
\text { Squares }\end{array}$ & df & \multicolumn{1}{c|}{$\begin{array}{c}\text { Mean } \\
\text { Square }\end{array}$} & \multicolumn{1}{c|}{$\mathrm{F}$} & \multicolumn{1}{c|}{$\begin{array}{c}\text { Partial } \\
\text { Eta } \\
\text { Squared }\end{array}$} & $\begin{array}{c}\text { Noncent. } \\
\text { Parameter }\end{array}$ & $\begin{array}{c}\text { Observed } \\
\text { Power(a) }\end{array}$ \\
\hline Intercept & 19941.075 & 1 & 19941.075 & 548.802 & .000 & .955 & 548.802 & 1.000 \\
\hline gender & 21.633 & 1 & 21.633 & .595 & .447 & .022 & .595 & .115 \\
\hline ethnicity & 16.920 & 2 & 8.460 & .233 & .794 & .018 & .466 & .083 \\
\hline $\begin{array}{l}\text { gender } \\
\text { ethnicity }\end{array}$ & 23.989 & 2 & 11.995 & .330 & .722 & .025 & .660 & .097 \\
\hline Error & 944.727 & 26 & 36.336 & & & & & \\
\hline
\end{tabular}

(a) Computed using alpha $=.05$ 
EA Tests of Within-Subjects Contrasts

\begin{tabular}{|l|l|r|r|r|r|r|r|r|r|}
\hline Source & ENV_ATT & $\begin{array}{c}\text { Type III } \\
\text { Sum of } \\
\text { Squares }\end{array}$ & \multicolumn{1}{c|}{$\begin{array}{c}\text { Mean } \\
\text { Square }\end{array}$} & \multicolumn{1}{c|}{$\mathrm{F}$} & \multicolumn{1}{c|}{ Sig. } & $\begin{array}{c}\text { Partial } \\
\text { Eta } \\
\text { Squared }\end{array}$ & $\begin{array}{c}\text { Noncent. } \\
\text { Parameter }\end{array}$ & $\begin{array}{l}\text { Observed } \\
\text { Power(a) }\end{array}$ \\
\hline ENV_ATT & Linear & 1.150 & 1 & 1.150 & .190 & .667 & .007 & .190 & .070 \\
\hline $\begin{array}{l}\text { ENV_ATT* } \\
\text { gender }\end{array}$ & Linear & 1.992 & 1 & 1.992 & .329 & .571 & .012 & .329 & .086 \\
\hline $\begin{array}{l}\text { ENV_ATT* } \\
\text { ethnicity }\end{array}$ & Linear & 28.070 & 2 & 14.035 & 2.316 & .119 & .151 & 4.632 & .427 \\
\hline $\begin{array}{l}\text { ENV_ATT } \\
\text { gender * } \\
\text { ethnicity }\end{array}$ & Linear & .956 & 2 & .478 & .079 & .924 & .006 & .158 & .061 \\
\hline Error(ENV_ATT) & Linear & 157.564 & 26 & 6.060 & & & & & \\
\hline
\end{tabular}

(a) Computed using alpha $=.05$

\section{EA Tests of Between-Subjects Effects}

\begin{tabular}{|l|r|r|r|r|r|r|r|r|}
\hline Source & $\begin{array}{c}\text { Type III } \\
\text { Sum of } \\
\text { Squares }\end{array}$ & \multicolumn{1}{c|}{ df } & \multicolumn{1}{c|}{$\begin{array}{c}\text { Mean } \\
\text { Square }\end{array}$} & \multicolumn{1}{c|}{ F } & \multicolumn{1}{c|}{$\begin{array}{c}\text { Partial } \\
\text { Eta } \\
\text { Squared }\end{array}$} & $\begin{array}{c}\text { Noncent. } \\
\text { Parameter }\end{array}$ & $\begin{array}{c}\text { Observed } \\
\text { Power(a) }\end{array}$ \\
\hline Intercept & 23710.407 & 1 & 23710.407 & 2430.809 & .000 & .989 & 2430.809 & 1.000 \\
\hline gender & 22.186 & 1 & 22.186 & 2.275 & .144 & .080 & 2.275 & .306 \\
\hline ethnicity & 17.246 & 2 & 8.623 & .884 & .425 & .064 & 1.768 & .186 \\
\hline $\begin{array}{l}\text { gender } \\
\text { ethnicity }\end{array}$ & 21.038 & 2 & 10.519 & 1.078 & .355 & .077 & 2.157 & .218 \\
\hline Error & 253.607 & 26 & 9.754 & & & & & \\
\hline
\end{tabular}

(a) Computed using alpha $=.05$ 
Appendix B: Learning Outcomes \& Coverage for River School Programming 


\begin{tabular}{|c|c|c|c|c|c|c|c|}
\hline \multicolumn{8}{|c|}{ Overarching Learning Themes } \\
\hline \multicolumn{2}{|c|}{$\begin{array}{l}\text { I - Conceptual } \\
\text { Understanding of } \\
\text { Watershed } \\
\text { System/Function }\end{array}$} & \multicolumn{2}{|c|}{$\begin{array}{l}\text { II - Watershed } \\
\text { Ecosystems, Dynamic } \\
\text { Water Quality Model \& } \\
\text { Ecosystem Functions (e.g. } \\
\text { animal habitat, pollution) }\end{array}$} & \multicolumn{2}{|c|}{$\begin{array}{l}\text { III - Contextual } \\
\text { Applications of Watershed } \\
\text { Concepts, Sense of Place } \\
\text { in Watershed }\end{array}$} & \multicolumn{2}{|c|}{$\begin{array}{l}\text { IV - Stewardship of } \\
\text { Watershed: Affective } \\
\text { Change \& Awareness } \\
\text { Development of Science } \\
\text { and Society Issues }\end{array}$} \\
\hline \multicolumn{2}{|c|}{ Knowledge Question 1} & \multicolumn{2}{|c|}{ Knowledge Question 4} & \multicolumn{2}{|c|}{ Knowledge Question 2} & \multicolumn{2}{|c|}{ Knowledge Question 3} \\
\hline \begin{tabular}{|l} 
Lesson, \\
Learning \\
Objectives
\end{tabular} & Coverage & \begin{tabular}{|l|} 
Lesson, \\
Learning \\
Objectives
\end{tabular} & Coverage & \begin{tabular}{|l|} 
Lesson, \\
Learning \\
Objectives \\
\end{tabular} & Coverage & \begin{tabular}{|l} 
Lesson, \\
Learning \\
Objectives
\end{tabular} & Coverage \\
\hline $\begin{array}{l}\text { What is a } \\
\text { Watershed? }\end{array}$ & & Ethnobotany & & \begin{tabular}{|l} 
What is a \\
Watershed?
\end{tabular} & & \begin{tabular}{|l} 
What is a \\
watershed?
\end{tabular} & \\
\hline $\begin{array}{l}\text { Students will } \\
\text { be able to } \\
\text { define what a } \\
\text { watershed is }\end{array}$ & & \begin{tabular}{|l|} 
Students will \\
be able to list \\
at least three \\
traditional uses \\
of native \\
plants
\end{tabular} & & $\begin{array}{l}\text { Students will } \\
\text { be able to } \\
\text { name the } \\
\text { watershed in } \\
\text { which their } \\
\text { school is } \\
\text { located }\end{array}$ & & $\begin{array}{l}\text { Students will } \\
\text { be able to list } \\
\text { direct actions } \\
\text { that protect } \\
\text { and restore } \\
\text { watershed } \\
\text { function }\end{array}$ & \\
\hline $\begin{array}{l}\text { Who Polluted } \\
\text { the Blue } \\
\text { River? }\end{array}$ & & $\begin{array}{l}\text { Riparian } \\
\text { Plants }\end{array}$ & & $\begin{array}{l}\text { Who Polluted } \\
\text { the Blue } \\
\text { River? }\end{array}$ & & Fish Biology & \\
\hline $\begin{array}{l}\text { Students will } \\
\text { be able to } \\
\text { define what a } \\
\text { watershed is }\end{array}$ & & \begin{tabular}{|l} 
Students will \\
be able to \\
identify at \\
least two \\
species of \\
riparian plants \\
found in the \\
Blue River \\
Watershed \\
\end{tabular} & & $\begin{array}{l}\text { Students will } \\
\text { be able to } \\
\text { name the } \\
\text { watershed in } \\
\text { which their } \\
\text { school is } \\
\text { located }\end{array}$ & & $\begin{array}{l}\text { Students will } \\
\text { be able to } \\
\text { brainstorm } \\
\text { ideas for } \\
\text { improving } \\
\text { habitats for } \\
\text { fish }\end{array}$ & \\
\hline Field Trip $\# 1$ & & Bird Migration & & Field Trip $\# 1$ & & Water Cycle & \\
\hline $\begin{array}{l}\text { Watershed } \\
\text { Model } \\
\text { Activity }\end{array}$ & & \begin{tabular}{|l|} 
Students will \\
be able to list \\
at least two \\
species of \\
animals in the \\
Pacific \\
Northwest that \\
migrate
\end{tabular} & & $\begin{array}{l}\text { Watershed } \\
\text { Model Activity }\end{array}$ & & $\begin{array}{l}\text { Students will } \\
\text { be able to } \\
\text { compare and } \\
\text { contrast the } \\
\text { effects of } \\
\text { different } \\
\text { water cycle } \\
\text { locations on } \\
\text { water quality } \\
\end{array}$ & \\
\hline \begin{tabular}{|l|} 
Total \\
Coverage
\end{tabular} & & \begin{tabular}{|l} 
Macroinverteb \\
rates
\end{tabular} & & \begin{tabular}{|l|}
$\begin{array}{l}\text { Macroinverteb } \\
\text { rates }\end{array}$ \\
\end{tabular} & & Field Trip \#1 & \\
\hline
\end{tabular}




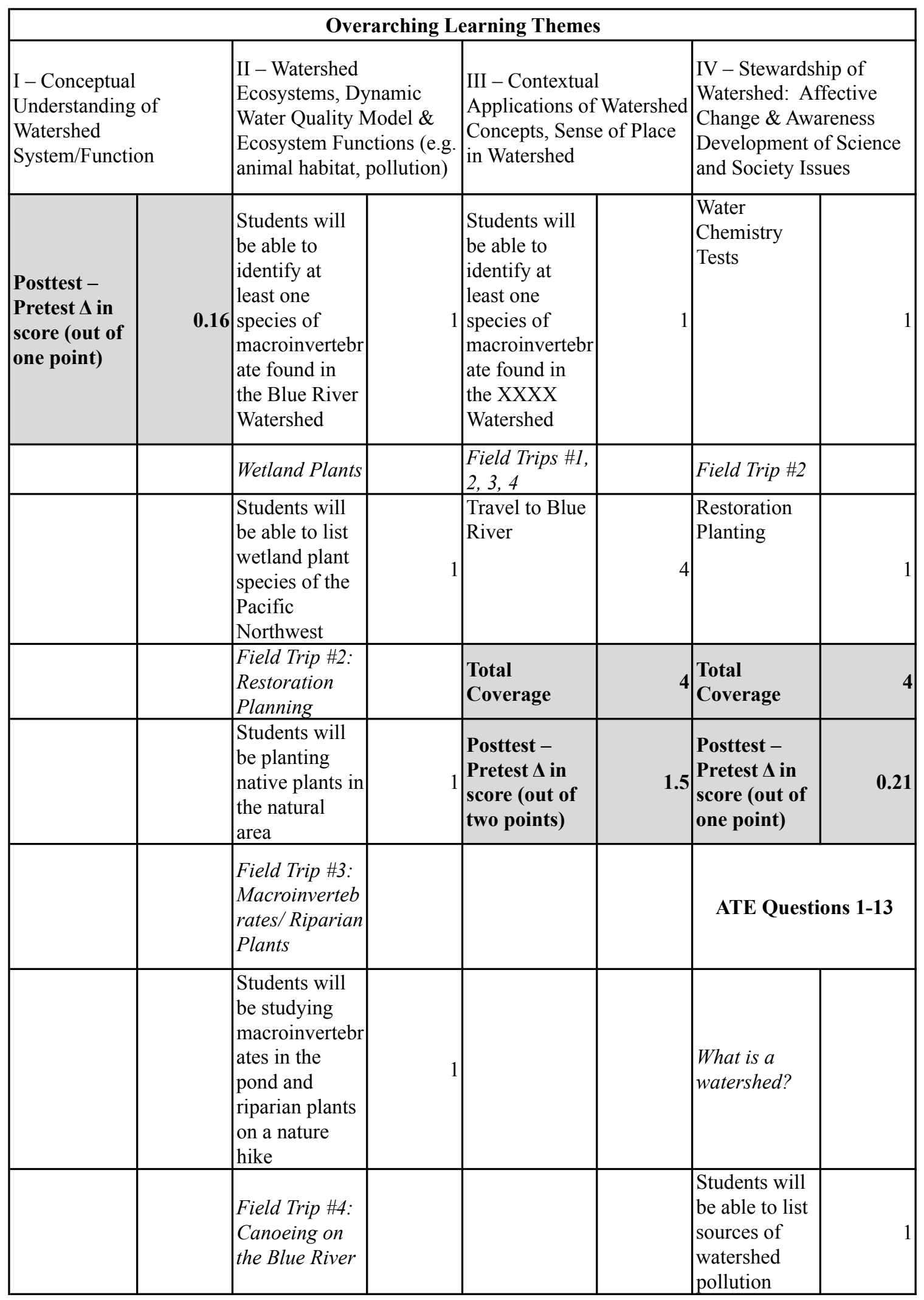




\begin{tabular}{|c|c|c|c|c|c|}
\hline \multicolumn{6}{|c|}{ Overarching Learning Themes } \\
\hline \multirow[t]{2}{*}{$\begin{array}{l}\text { I - Conceptual } \\
\text { Understanding of } \\
\text { Watershed } \\
\text { System/Function }\end{array}$} & \multicolumn{2}{|c|}{$\begin{array}{l}\text { II - Watershed } \\
\text { Ecosystems, Dynamic } \\
\text { Water Quality Model \& } \\
\text { Ecosystem Functions (e.g. } \\
\text { animal habitat, pollution) }\end{array}$} & $\begin{array}{l}\text { III - Contextual } \\
\text { Applications of Watershed } \\
\text { Concepts, Sense of Place } \\
\text { in Watershed }\end{array}$ & \multicolumn{2}{|c|}{$\begin{array}{l}\text { IV - Stewardship of } \\
\text { Watershed: Affective } \\
\text { Change \& Awareness } \\
\text { Development of Science } \\
\text { and Society Issues }\end{array}$} \\
\hline & $\begin{array}{l}\text { Students will } \\
\text { be canoeing a } \\
\text { section of the } \\
\text { Blue River and } \\
\text { observing } \\
\text { animals and } \\
\text { plants }\end{array}$ & 1 & & $\begin{array}{l}\text { Students will } \\
\text { be able to list } \\
\text { direct actions } \\
\text { that protect } \\
\text { and restore } \\
\text { watershed } \\
\text { function }\end{array}$ & \\
\hline & \begin{tabular}{|l} 
Total \\
Coverage
\end{tabular} & 4 & & $\begin{array}{l}\text { Who Polluted } \\
\text { the Blue } \\
\text { River? } \\
\end{array}$ & \\
\hline & $\begin{array}{l}\text { Posttest - } \\
\text { Pretest } \Delta \text { in } \\
\text { score (out of } \\
\text { three points) }\end{array}$ & .34 & & $\begin{array}{l}\text { Students will } \\
\text { be able to list } \\
\text { sources of } \\
\text { watershed } \\
\text { pollution } \\
\end{array}$ & \\
\hline & Knowledge $Q$ & & & \begin{tabular}{|l} 
Students will \\
be able to list \\
historic \\
sources of \\
watershed \\
pollution in \\
the Columbia \\
Slough \\
Watershed
\end{tabular} & \\
\hline & \begin{tabular}{|l} 
What is a \\
Watershed?
\end{tabular} & & & Fish Biology & 1 \\
\hline & $\begin{array}{l}\text { Students will } \\
\text { be able to list } \\
\text { sources of } \\
\text { watershed } \\
\text { pollution }\end{array}$ & 1 & & $\begin{array}{l}\text { Students will } \\
\text { be able to list } \\
\text { healthy and } \\
\text { unhealthy } \\
\text { habitats for } \\
\text { fish } \\
\end{array}$ & \\
\hline & $\begin{array}{l}\text { Who Polluted } \\
\text { the Slough? }\end{array}$ & & & \begin{tabular}{|l} 
Students will \\
be able to \\
brainstorm \\
ideas for \\
improving \\
habitats for \\
fish \\
\end{tabular} & \\
\hline & $\begin{array}{l}\text { Students will } \\
\text { be able to list } \\
\text { sources of } \\
\text { watershed } \\
\text { pollution } \\
\end{array}$ & 1 & & Water Cycle & \\
\hline
\end{tabular}




\begin{tabular}{|c|c|c|c|c|}
\hline \multicolumn{5}{|c|}{ Overarching Learning Themes } \\
\hline $\begin{array}{l}\text { I - Conceptual } \\
\text { Understanding of } \\
\text { Watershed } \\
\text { System/Function }\end{array}$ & \begin{tabular}{|l} 
II - Watershed \\
Ecosystems, Dynamic \\
Water Quality Model \& \\
Ecosystem Functions (e.g. \\
animal habitat, pollution)
\end{tabular} & $\begin{array}{l}\text { III - Contextual } \\
\text { Applications of Watershed } \\
\text { Concepts, Sense of Place } \\
\text { in Watershed }\end{array}$ & \multicolumn{2}{|c|}{$\begin{array}{l}\text { IV - Stewardship of } \\
\text { Watershed: Affective } \\
\text { Change \& Awareness } \\
\text { Development of Science } \\
\text { and Society Issues }\end{array}$} \\
\hline & \begin{tabular}{|l|} 
Students will \\
be able to list \\
historic \\
sources of \\
watershed \\
pollution in the \\
Blue River \\
Watershed
\end{tabular} & & $\begin{array}{l}\text { Students will } \\
\text { be able to } \\
\text { compare and } \\
\text { contrast the } \\
\text { effects of } \\
\text { different } \\
\text { locations on } \\
\text { water quality }\end{array}$ & 1 \\
\hline & \begin{tabular}{|l|} 
Water \\
Chemistry \\
\end{tabular} & & \begin{tabular}{|l} 
Field Trips 1, \\
$2,3,4$
\end{tabular} & \\
\hline & \begin{tabular}{|l|} 
Students will \\
be able to \\
define what \\
$\mathrm{pH}$, dissolved \\
oxygen and \\
temperature is \\
\end{tabular} & & $\begin{array}{l}\text { Restoration } \\
\text { planting }\end{array}$ & 1 \\
\hline & $\begin{array}{l}\text { Students will } \\
\text { be able to } \\
\text { describe water } \\
\text { chemistry } \\
\text { parameters of } \\
\text { a healthy water } \\
\text { body }\end{array}$ & & $\begin{array}{l}\text { Macroinverte } \\
\text { brate } \\
\text { sampling }\end{array}$ & 1 \\
\hline & $\begin{array}{l}\text { Macroinverteb } \\
\text { rates }\end{array}$ & & $\begin{array}{l}\text { Watershed } \\
\text { model }\end{array}$ & 1 \\
\hline & $\begin{array}{l}\text { Students will } \\
\text { be able to } \\
\text { describe how } \\
\text { macroinvertebr } \\
\text { ates are } \\
\text { indicators of } \\
\text { water quality } \\
\end{array}$ & & \begin{tabular}{|l} 
Spending \\
Time \\
Outdoors
\end{tabular} & 3 \\
\hline & Fish Biology & & $\begin{array}{l}\text { Total } \\
\text { Coverage }\end{array}$ & 4 \\
\hline & $\begin{array}{l}\text { Students will } \\
\text { be able to list } \\
\text { healthy and } \\
\text { unhealthy } \\
\text { habitats for } \\
\text { fish } \\
\end{array}$ & & $\begin{array}{l}\text { Posttest }- \\
\text { Pretest } \Delta \text { in } \\
\text { score } \\
(\text { optimal } \\
\text { score }=65 \\
\text { points) } \\
\end{array}$ & 0.31 \\
\hline & Water Cycle & & & \\
\hline
\end{tabular}




\begin{tabular}{|c|c|c|c|c|}
\hline \multicolumn{5}{|c|}{ Overarching Learning Themes } \\
\hline $\begin{array}{l}\text { I - Conceptual } \\
\text { Understanding of } \\
\text { Watershed } \\
\text { System/Function }\end{array}$ & \multicolumn{2}{|c|}{$\begin{array}{l}\text { II - Watershed } \\
\text { Ecosystems, Dynamic } \\
\text { Water Quality Model \& } \\
\text { Ecosystem Functions (e.g. } \\
\text { animal habitat, pollution) }\end{array}$} & $\begin{array}{l}\text { III - Contextual } \\
\text { Applications of Watershed } \\
\text { Concepts, Sense of Place } \\
\text { in Watershed }\end{array}$ & $\begin{array}{l}\text { IV - Stewardship of } \\
\text { Watershed: Affective } \\
\text { Change \& Awareness } \\
\text { Development of Science } \\
\text { and Society Issues }\end{array}$ \\
\hline & $\begin{array}{l}\text { Students will } \\
\text { be able to } \\
\text { compare and } \\
\text { contrast the } \\
\text { effects of } \\
\text { different water } \\
\text { cycle locations } \\
\text { on water } \\
\text { quality } \\
\end{array}$ & 1 & & \\
\hline & Field Trip \#1 & & & \\
\hline & $\begin{array}{l}\text { Watershed } \\
\text { Model Activity }\end{array}$ & 1 & & \\
\hline & \begin{tabular}{|l|} 
Water \\
Chemistry \\
Tests \\
\end{tabular} & 1 & & \\
\hline & Field Trip \#3 & & & \\
\hline & $\begin{array}{l}\text { Students will } \\
\text { be studying } \\
\text { macroinvertebr } \\
\text { ates }\end{array}$ & 1 & & \\
\hline & \begin{tabular}{|l|} 
Total \\
Coverage \\
\end{tabular} & 4 & & \\
\hline & $\begin{array}{l}\text { Posttest }- \\
\text { Pretest } \Delta \text { in } \\
\text { score (out of } \\
\text { two points) } \\
\end{array}$ & 0.29 & & \\
\hline
\end{tabular}


Appendix C: Instruments and Interview Questions 
Pre- and Post Knowledge \& Attitude Questionnaire for River School

Name: Date:

Gender: $\square$ Male $\square$ Female

PART 1: Please answer the following questions by checking the best answer. If you don't know the answer, just mark, "I don't know." You won't be graded on this test.

1. What is a watershed?

a. A shed with water in it.

b. Where people get their drinking water from

c. An area of land where all the water drains to one stream

d. I don't know

PART 2: Write out the best answer to the question. If you don't know the answer, just write, "I don't know."

2. What watershed is your school in?

3. What are some things that people can do to keep rivers and streams healthy and clean?

4. List 3 native plants or animals that live in this area.

5. Describe two ways that you can tell if a body of water is healthy. 
PART 3: Please circle the number that best matches your feelings for the following statements. Circle ONLY ONE per statement.

\begin{tabular}{|c|c|c|c|c|c|}
\hline In the next 6 months, I intend to... & 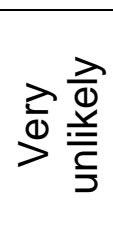 & 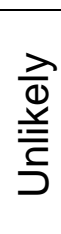 & $\begin{array}{l}\text { ते } \\
\stackrel{\vec{d}}{\Xi}\end{array}$ & 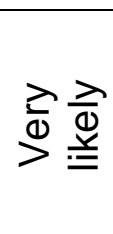 & 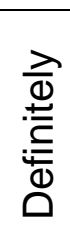 \\
\hline $\begin{array}{l}\text { 1. Change one thing that I do around my house } \\
\text { and neighborhood to prevent water pollution. }\end{array}$ & 1 & 2 & 3 & 4 & 5 \\
\hline $\begin{array}{l}\text { 2. Tell others about ways they can protect our } \\
\text { rivers and streams. }\end{array}$ & 1 & 2 & 3 & 4 & 5 \\
\hline 3. Volunteer to help the watershed. & 1 & 2 & 3 & 4 & 5 \\
\hline $\begin{array}{l}\text { 4. Tell my family one thing we can do to stop } \\
\text { water pollution. }\end{array}$ & 1 & 2 & 3 & 4 & 5 \\
\hline $\begin{array}{l}\text { 5. Do something outdoors to help keep our } \\
\text { rivers and streams cleaner. }\end{array}$ & 1 & 2 & 3 & 4 & 5 \\
\hline 6. Spend time outdoors in nature. & 1 & 2 & 3 & 4 & 5 \\
\hline
\end{tabular}

PART 4: How much do you agree with the following statements? Circle ONLY ONE per statement.

\begin{tabular}{|c|c|c|c|c|c|}
\hline & 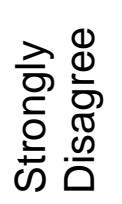 & 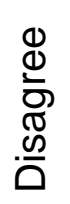 & 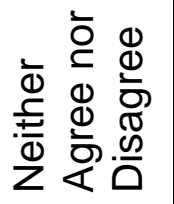 & - & 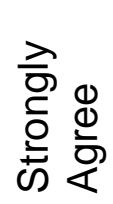 \\
\hline $\begin{array}{l}\text { 7. I think rivers and streams in our city } \\
\text { are polluted. }\end{array}$ & 1 & 2 & 3 & 4 & 5 \\
\hline $\begin{array}{l}\text { 8. It is my personal responsibility to help } \\
\text { protect natural areas such as streams, } \\
\text { rivers, and wetlands. }\end{array}$ & 1 & 2 & 3 & 4 & 5 \\
\hline $\begin{array}{l}\text { 9. My family thinks it is important to keep } \\
\text { our rivers and streams clean. }\end{array}$ & 1 & 2 & 3 & 4 & 5 \\
\hline $\begin{array}{l}\text { 10. I think the local government cares } \\
\text { about our rivers and streams. }\end{array}$ & 1 & 2 & 3 & 4 & 5 \\
\hline $\begin{array}{l}\text { 11. My teacher thinks it is important to } \\
\text { help protect our rivers and streams. }\end{array}$ & 1 & 2 & 3 & 4 & 5 \\
\hline $\begin{array}{l}\text { 12. I would work on a project to help our } \\
\text { rivers and streams ONLY if I had to for } \\
\text { school. }\end{array}$ & 1 & 2 & 3 & 4 & 5 \\
\hline $\begin{array}{l}\text { 13. I think we can make our rivers and } \\
\text { streams cleaner for people and } \\
\text { wildlife. }\end{array}$ & 1 & 2 & 3 & 4 & 5 \\
\hline
\end{tabular}

\section{Student Focus Group Questions}




\section{Semi-Structured Interview Protocol}

1. What did you learn this year? What do you think will really stick with you next year and beyond?

2. Thinking about Slough School, what did you learn from those experiences - the classroom visits from Ms. Felice and the field trips?

3. What was your favorite activity or activities in science?

4. What about the Slough School activities? What were your favorites?

5. What was the most confusing thing you learned, or what you didn't like learning about this year?

6. What about the Slough School activities?

7. Has the way you think about where you live changed during the course of the year? How so?

8. How has Slough School contributed to these changes?

9. How do you feel you best learn science? 


\section{Teacher Questions for River School Study}

Script: Today is (date), and I'm interview (person) about their experiences with the Columbia Slough School program at Ockley Green. All information in this interview will stay confidential, and no information will be shared with anyone else except for with the consent.

1. In your opinion, which classroom lessons worked best?
a. What is a watershed?
b. Water chemistry/watershed model
c. Water Cycle (bead game where students had to move around)
d. Wetland introduction
e. Riparian Plants
f. Animal Adaptations (skulls, draw an animal)
g. Macroinvertebrates (macros in jars)
h. Ethnobotany (brought plants, Native American baskets, etc)
i. Bird Migration (read the story)

2. Are there any classroom lessons that you feel didn't work?

3. Thinking about the students, now, what lessons do you think they liked the best?

a. What lessons did they not like?

b. Did they enjoy the field trips?

4. Did the classroom lessons fit in well with state and local science standards?

5. Did field trips reinforce concepts learned in the classroom lessons, in your opinion?

a. What evidence?

6. What related activities did you do with your students during the course of the year?

a. What other activities do you know that students did that might be similar?

7. Do you think this program has changed attitudes or behavior towards the environment?

a. What evidence do you have? 
8. Do you think this program benefits all races/genders/ethnocultural groups equally?

a. If not, why not?

b. Which groups benefit/do not benefit?

9. What things (choice of lessons, order, etc), if any, would you change for next year?

10. Would you recommend this program to other teachers for use in their classrooms? 


\section{Observation Sheet}

\section{Part 1: Educational Goals}

1. List the major knowledge goals of the class:

2. Did the teacher incorporate each of the goals into their presentation? $\quad \mathrm{Y} \quad \mathrm{N}$

3. If no, which ones were not included?

4. The knowledge pertaining to the educational goals addressed was clearly imparted during the presentation

\begin{tabular}{|c|c|c|c|}
\hline $\begin{array}{l}\text { Strongly } \\
\text { Disagree }\end{array}$ & & $\begin{array}{c}\text { Strongly } \\
\text { Agree }\end{array}$ \\
\hline 1 & 2 & 3 & 4 \\
\hline
\end{tabular}

Notes:

Part 2: Student interactions

5. Students seemed interested in the subject matter

\begin{tabular}{|c|c|c|c|}
\hline $\begin{array}{l}\text { Strongly } \\
\text { Disagree }\end{array}$ & & & $\begin{array}{c}\text { Strongly } \\
\text { Agree }\end{array}$ \\
\hline 1 & 2 & 3 & 4 \\
\hline
\end{tabular}

Notes:

6. Students paid attention during the presentation, and were not doing other things

\begin{tabular}{|c|c|c|c|}
\hline $\begin{array}{l}\text { Strongly } \\
\text { Disagree }\end{array}$ & & & $\begin{array}{c}\text { Strongly } \\
\text { Agree }\end{array}$ \\
\hline 1 & 2 & 3 & 4 \\
\hline
\end{tabular}

Notes:

7. Students interacted with the teacher when requested

\begin{tabular}{|c|c|c|c|}
\hline $\begin{array}{l}\text { Strongly } \\
\text { Disagree }\end{array}$ & & $\begin{array}{c}\text { Strongly } \\
\text { Agree }\end{array}$ \\
\hline 1 & 2 & 3 & 4 \\
\hline
\end{tabular}

Notes: 